\title{
WAKAF TUNAI SEBAGAI ALTERNATIF MEKANISME REDISTRIBUSI KEUANGAN ISLAM
}

\author{
Oleh Syafrudin Arif ${ }^{1}$
}

Abstract

Waqf itself is a principle that entails generous applications in developing the non-profit, nongovernmental sector and increasing the quantity of welfare services to improve socio-economic welfare of a society. This provides justification for theoretical studies of the application of Awqaf and the development of their properties in Muslim countries and communities. The cash waqf is expected to be an alternative instruments for the poverty alleviation programs. In the Islamic socioeconomic concept, there is a source of social fund that is economically and politically free of charge, namely cash waqf. The objective of the paper is to investigate how this institution can be used in contemporary times to solve economic problems in Muslim society, especially in Indonesia. It is believed that if the potency of waqf is empowered by productive method, it will give more contribution to redistribute assets and opportunities, capacity building and wealth creation, and to extend income support.

Kata kunci: wakaf tunai, potensi, redistributif, kemiskinan (cash waqf, potentiallity, redistributive, poverty)

\section{Pendahuluan}

Kemiskinan dan ketimpangan pendapatan merupakan persoalan rumit yang dihadapi oleh negara. Sifatnya massif dan struktural serta meluas yang terjadi pada setiap lapisan masyarakat. Oleh karena itu, karena negara mempunyai dan memegang kekuasaan sekaligus kekuatan ekonomi paling besar. Sehingga negaralah yang sewajarnya mengemban tugas mulia untuk mengentaskan kemiskinan. Sekalipun begitu, tidak menutup kemungkinan setiap lapisan masyarakat mempunyai peranan yang signifikan dalam mengentaskan kemiskinan. Bahkan peran agama juga sangat dimungkinkan dalam hal ini. Sebagaimana ditunjukkan dalam ajaran Islam tentang zakat dan juga wakaf, penerapan keduanya berpotensi besar mengurangi secara signifikan angka kemiskinan yang bersifat "struktural" tersebut. ${ }^{2}$.

${ }^{1}$ Penulis adalah dosen tetap Sekolah Tinggi Agama Islam Negeri (STAIN) Tulungagung Jawa Timur dalm bidang Manajemen Keuangan Syariah.

${ }^{2}$ Riza Prima Henda, dkk. (2003). Kemiskinan dan Kemandirian: Catatan Perjalanan dan Refleksi Bina Swadaya. Jakarta: Yayasan Bina Swadaya, hal. 37. Kemiskinan struktural adalah keadaan serba kekurangan yang diikuti oleh berbagai keadaan yang menekan kehidupan yang saling mempengaruhi dan menyejarah. Keadaan tersebut bukanlah keadaan yang dikehendaki oleh si miskin, melainkan sesuatu yang tidak bisa dihindari dengan kekuatan yang ada pada dirinya. Tidak terpenuhinya berbagai 
Ada banyak cara yang berpotensi mengentaskan kemiskinan tersebut. Cara menanggulangi kemiskinan bisa berupa: ${ }^{3}$ (a) pengembangan kelembagaan (institutional building) (b) akses (c) kesejahteraan (welfare). (d) penyadaran (conscientization). (e) partisipasi politik (political participation). Dalam makalah ini, tema wakaf tunai akan dipaparkan dalam kerangka pengembangan kelembagaan (institutional building) atau bisa disebut "mekanisme keuangan." Karena potensi wakaf tunai yang luar biasa untuk redistribusi ekonomi.

Potensi wakaf tunai di Indonesia luar biasa. Hal itu kita ketahui dari data yang ada. Berdasarkan data yang ada di Departemen Agama, jumlah tanah wakaf di Indonesia sebanyak 430,766 lokasi dengan luas mencapai 1,615,791,832.27 meter persegi $^{4}$ yang tersebar lebih dari 366.595 lokasi di seluruh Indonesia. Dilihat dari sumber daya alam atau tanahnya (resources capital) jumlah harta wakaf di Indonesia merupakan jumlah harta wakaf terbesar di seluruh dunia. Ini merupakan tantangan bagi umat Islam Indonesia untuk memfungsikan harta wakaf tersebut secara maksimal sehingga tanah-tanah tersebut mampu mensejahterakan umat Islam di Indonesia sesuai dengan fungsi dan tujuan ajaran wakaf yang sebenarnya. Sayangnya, potensi itu masih belum dimanfaatkan secara optimal, karena berbagai faktor. Maka, langkah yang tak bisa ditawar lagi yaitu memberdayakan potensinya dengan memproduktifkan aset-aset wakaf tersebut. Jika bangsa ini mampu mengoptimalkan potensi wakaf yang begitu besar itu, tentu kemakmuran dan kesejahteraan masyarakat lebih terjamin.

Perwakafan di Indonesia jauh tertinggal dibanding negara-negara yang mayoritas berpenduduk Islam lain, seperti Mesir, ${ }^{5}$ Aljazair, Arab Saudi, ${ }^{6}$ Kuwait, dan

kebutuhan dan pelayanan dasar yang diperlukan oleh seseorang untuk hidup dan berkembang secara layak.

${ }^{3}$ Ibid., hal. 48.

${ }^{4}$ Direktorat Pemberdayaan Wakaf, "Data Luas dan Lokasi Tanah Wakaf Nasional Sampai Dengan Tahun 2008”, Jakarta, 22 April 2008.

${ }^{5}$ Mesir adalah salah satu negara yang memiliki harta wakaf cukup banyak karena sejak masuknya Islam di Mesir, pemerintahnya selalu mengembangkan harta wakaf. Salah satu di antara harta wakaf yang sangat besar dan cukup dikenal di dunia Islam adalah Universitas al-Azhar yang sampai sekarang masih diminati oleh mahasiswa dari seluruh dunia. Universitas ini didirikan pada masa Khilafah Fathimiyyah. Perkembangan pengelolaan wakaf di Mesir sejak awal memang sangat mengagumkan, bahkan keberhasilannya dijadikan contoh bagi pengembangan wakaf di negara-negara lain. Wakaf di Mesir dikelola oleh Badan Wakaf Mesir yang berada di bawah Wizaratul Auqaf (Kementerian Wakaf). Salah satu di antara kemajuan yang telah dicapai oleh Badan Wakaf Mesir adalah berperannya harta wakaf dalam meningkatkan ekonomi masyarakat. Hal ini disebabkan benda yang diwakafkan beragam, baik berupa benda tidak bergerak maupun benda bergerak, yang dikelola secara baik dan benar. Pengelolaannya dilakukan dengan cara menginvestasikan harta wakaf di bank Islam (jika berupa uang) dan berbagai perusahaan, seperti perusahan besi dan baja. Untuk menyempurnakan pengembangan wakaf, Badan Wakaf membeli saham dan obligasi dari perusahaan-perusahaan penting. Hasil pengembangan wakaf yang ditanamkan di berbagai perusahaan tersebut di samping untuk mendirikan tempat-tempat ibadah dan lembaga-lembaga pendidikan, juga dimanfaatkan untuk membantu kehidupan masyarakat (fakir miskin, anak yatim, dan para pedagang kecil), kesehatan masyarakat (mendirikan rumah sakit dan menyediakan obat-obatan bagi masyarakat), pengembangan ilmu 
Turki. ${ }^{7}$ Mereka jauh-jauh hari sudah mengelola wakaf ke arah produktif. Bahkan, di negara yang penduduk muslimnya minor, pengembangan wakaf juga tak kalah produktif. Singapura misalnya, aset wakafnya, jika dikruskan, berjumlah S\$250 juta. Untuk mengelolanya, Majelis Ugama Islam Singapura (MUIS) membuat anak perusahaan bernama Wakaf Real Estate Singapura (WAREES).

Kalau mereka bisa, mengapa Indonesia yang merupakan negara berpenduduk muslim terbesar di dunia ini tak mampu. Penulis yakin, masyarakat Islam Indonesia mampu melakukan, bahkan lebih dari itu, jika benar-benar serius menangani hal ini. Apalagi, pemberdayaan wakaf di Indonesia kini sudah diakomodir secara formal oleh peraturan perundangan yang sangat progresif dalam mengakomodir hukum fiqh yaitu UU No. 41 tahun 2004 tentang wakaf dan PP No. 42 tahun 2006 tentang pedoman pelaksanaannya. Kalau begitu, sekarang tinggal action saja, tak perlu banyak berwacana. Kalau dulu, banyak orang berdiskusi dan berharap adanya lembaga khusus yang menangani perwakafan di Indonesia, kini BWI sudah berdiri (sejak 2007). Tinggal bagaimana memaksimalkan lembaga independen amanat undang-undang itu. (Bab VI, pasal 7, UU No. 41 tahun 2004).

Pemberdayaan wakaf kita pahami dalam arti "redistribusi ekonomi." Redistribusi ekonomi berarti penyebaran kekayaan dari sebagian kelompok kepada kelompok yang lain baik secara tunai ataupun tidak. Redistribusi juga mencakup pemberian layanan umum (public services), seperti kesehatan dan pendidikan dari satu kelompok ke kelompok lainnya. Sehingga masyarakat merasakan manfaat material dan kemudian redistribusi itu juga menimbulkan biaya. Oleh karena itu, penggerak atau

pengetahuan dalam berbagai bidang, dan berbagai pelatihan. Dengan dikembangkannya wakaf secara produktif, wakaf di Mesir dapat dijadikan salah satu lembaga yang diandalkan pemerintah untuk mewujudkan kesejahteraan umat. Sebagaimana diungkap Uswatun dengan mengutip dari Tarikh alDaulah al-Islamiyyah dan Idarah wa Tasmir Mumtalakat al-Auqaf.

${ }^{6}$ Saudi Arabia juga mempunyai semacam Badan Wakaf yang diberi nama Majelis Tinggi Wakaf. Majelis Tinggi Wakaf ada di bawah Kementerian Haji dan Wakaf. Majelis Tinggi Wakaf ini diatur dengan Ketetapan No. 574 tanggal 16 Rajab 1386 sesuai dengan Surat Keputusan Kerajaan No. M/35, tanggal 18 Rajab 1386. Adapun wewenang Majelis Tinggi Wakaf antara lain mengembangkan wakaf secara produktif dan mendistribusikan hasil pengembangan wakaf kepada mereka yang berhak. Sehubungan dengan hal itu, Majelis Tinggi Wakaf juga mempunyai wewenang untuk membuat program pengembangan wakaf, pendataan terhadap aset wakaf serta memikirkan cara pengelolaannya, menentukan langkah-langkah penanaman Modal, dan langkah-langkah pengembangan wakaf produktif lainnya, serta mempublikasikan hasil pengembangan wakaf kepada masyarakat. Lihat Uswatun Hasanah, Wakaf Produktif Untuk Kesejahteraan dalam Perspektif Hukum Islam di Indonesia. (Jakarta: Naskah Pidato Pengukuhan Guru Besar di Universitas Indonesia, 6 April 2009), hal. 32.

7 Di Turki, wakaf dikelola oleh Direktorat Jenderal Wakaf. Dalam mengembangkan wakaf, pengelola melakukan investasi di berbagai perusahaan, antara lain: Ayvalik and Aydem Olive Oil Corporation; Tasdelen Healthy Water Corporation; Auqaf Guraba Hospital; Taksim Hotel (Sheraton); Turkish Is Bank; Aydin Textile Industry; Black Sea Copper Industry; Contruction and Export/Import Corporation; Turkish Auqaf Bank. Hasil pengelolaan wakaf itu kemudian dimanfaatkan untuk kepentingan pendidikan, kesehatan, pemberdayaan ekonomi rakyat, dan kepentingan sosial lainnya. Uswatun Hasanah, Ibid., hal. 11. 
agen redistributif berfungsi sebagai perantara antara proses pemanfaatan redistribusi dan biaya redistribusi itu. Dalam hal ini, ada tiga jenis redistributive agent: pemerintah, individu dan institusi swasta. ${ }^{8}$ Kebijakan yang dilakukan agen-agen tersebut yang berupa seperti pajak, kedermawanan, beasiswa, termasuk wakaf diistilahkan sebagai mekanisme redistributif (redistributive mechanism). Jadi wakaf tunai dapat menjadi mekanisme redistributif yang luar biasa bagi masyarakat luas.

Namun persoalannya, masih populernya pemahaman bahwa harta wakaf adalah tanah dan bangunan, sehingga diperlukan penjelasan yang mudah kepada masyarakat bahwa harta wakaf dapat berupa harta bergerak. Bahwa wakaf harta bergerak ini sesuai dengan tujuan syariat wakaf, yaitu memberikan sesuatu supaya bermanfaat kepada masyarakat luas, dalam arti supaya harta wakaf itu dikelola secara produktif. Oleh karena itu, tulisan ini akan memaparkan dasar syariat wakaf, kemudian gambaran bahwa adanya wakaf harta bergerak tidak bertentangan dengan tujuan syariat wakaf dalam Islam. Juga di sini akan dipaparkan bagaimana meraih potensi wakaf dalam arti redistribusi ekonomi di Indonesia.

\section{Asal Mula Pengertian Wakaf}

Wakaf secara etimologi adalah al-habs (menahan)". Ia merupakan kata yang berbentuk masdar (gerund) dari ungkapan waqfu al-syai' yang pada dasarnya berarti menahan sesuatu. Dengan demikian, pengertian wakaf secara bahasa adalah menyerahkan tanah untuk orang-orang miskin untuk ditahan. Diartikan demikian karena barang milik itu dipegang dan ditahan orang lain, seperti menahan hewan ternak, tanah dan segala sesuatu. ${ }^{10}$

Secara gramatikal, penggunaan kata "auqafa" yang digabungkan dengan katakata segala jenis barang termasuk ungkapan yang tidak lazim (jelek). Yang benar adalah dengan menggunakan kata kerja "waqaftu" tanpa memakai hamzah (auqaftu). Adapun yang semakna dengan kata "habistu" adalah seperti ungkapan "waqaftu al-syai" aqifubu waqfan". ${ }^{11}$

Para ulama berbeda pendapat dalam memberi pengertian wakaf, sebagaimana tercantum buku-buku fiqh. Perbedaan tersebut membawa akibat yang berbeda pada hukum yang ditimbulkan. Definisi wakaf menurut ahli fiqh adalah sebagai berikut.

Pertama, Hanafiyah mengartikan wakaf sebagai menahan materi benda (al-'ain) milik wakif dan menyedekahkan atau mewakafkan manfaatnya kepada siapapun yang

${ }^{8}$ Birol Baskan, Waqf System As A Redistribution Mechanism In Ottoman Empire, Chicago: Northwestern University Department of Political Science, 2002, April, hal. 2.

${ }^{9}$ Ibn Manzur, Lisan al-Arab, jil. 11. (Kairo: al-Dar al-Misriyyah li al-Ta'lif wa al-Tarjamah, 1954), hal. 276.

${ }^{10}$ Muhammad Abid Abdullah al-Kabisi, Ahkam al-Waqf fi al-Syariah al-Islamiyah. (Baghdad: Mathba'ah al-Irsyad, 1977). Alih bahasa Ahrul Sani Faturrahman dkk, judul Indonesia: Hukum Wakaf, (Jakarta: DD Republika dan IIMan, 2004), hal. 37

${ }^{11}$ Sebagaimana dijelaskan al-Kabisi dengan merujuk kepada kamus al-Muhid dan Lisan al-Arab. 
diinginkan untuk tujuan kebajikan. ${ }^{12}$ Definisi wakaf tersebut menjelaskan bahwa kedudukan harta wakaf masih tetap tertahan atau terhenti di tangan wakif itu sendiri. Dengan artian, wakif masih menjadi pemilik harta yang diwakafkannya, manakala perwakafan hanya terjadi ke atas manfaat harta tersebut, bukan termasuk aset hartanya.

Kedua, Malikiyah berpendapat, wakaf adalah menjadikan manfaat suatu harta yang dimiliki (walaupun pemilikannya dengan cara sewa) untuk diberikan kepada orang yang berhak dengan satu akad (shighat) dalam jangka waktu tertentu sesuai dengan keinginan wakif. ${ }^{13}$ Definisi wakaf tersebut hanya menentukan pemberian wakaf kepada orang atau tempat yang berhak saja.

Ketiga, Syafi'iyah mengartikan wakaf dengan menahan harta yang bisa memberi manfaat serta kekal materi bendanya (al-'ain) dengan cara memutuskan hak pengelolaan yang dimiliki oleh wakif untuk diserahkan kepada Nazhir yang dibolehkan oleh syariah. ${ }^{14}$ Menurut Syaikh Syihabuddin al-Qalyubi, wakaf adalah habsul mali yumkinu al-intifa'u bibi ma'a baqa'I ainibi 'ala mashrafin mubahin (menahan harta yang bisa diambil manfaatnya dengan menjaga bentuk aslinya untuk disalurkan kepaa jalan yang dibolehkan). ${ }^{15}$ Golongan ini mensyaratkan harta yang diwakafkan harus harta yang kekal materi bendanya (al-'ain), dalam arti harta yang tidak mudah rusak atau musnah serta dapat diambil manfaatnya secara berterusan.

Keempat, Hanabilah mendefinisikan wakaf dengan bahasa yang sederhana, yaitu menahan asal harta (tanah) dan menyedekahkan manfaat yang dihasilkan. ${ }^{16}$ Demikianlah pengertian wakaf menurut para ulama ahli fiqih.

Sedangkan dalam konteks perundangan di Indonesia, nampaknya wakaf dimaknai secara spesifik dengan menemukan titik temu dari berbagai pendapat ulama tersebut. Hal ini dapat terlihat dalam rumusan pengertian wakaf dalam Undangundang Nomor 41 Tahun 2004 tentang wakaf, wakaf diartikan dengan perbuatan hukum Wakif untuk memisahkan dan/atau menyerahkan sebagian harta benda miliknya untuk dimanfaatkan selamanya atau untuk jangka waktu tertentu sesuai dengan kepentingannya guna keperluan ibadah dan/atau kesejahteraan umum menurut syariah. ${ }^{17}$ Rumusan dalam UU wakaf tersebut, jelas sekali merangkum berbagai pendapat para ulama fiqh tersebut di atas tentang makna wakaf, sehingga makna wakaf dalam konteks Indonesia lebih luas dan lebih komplit.

${ }^{12}$ Al-Imam Kamal al-Din Ibn 'Abd al-Rahid al-Sirasi Ibn al-Humam, Sharh Fath al-Qadir, jil. 6. (Beirut: Dar al- Kutub al-'Ilmiyyah, 1970), hal. 203.

${ }^{13}$ Syams al-Din al-Syaikh Muhammad al-Dasuqi, Hasyiyah al-Dasuqi 'ala al-Syarh al-Kabir, juz 2. (Beirut: Dar al-Fikr, tt.), hal. 187.

${ }^{14}$ Muhammad al-Khatib al-Syarbini, Mughni al-Muhtaj, juz 2. (Kairo: Syarikah Maktabah wa Matba'ah Mustafa al-Babi al-Halabi wa Awladih, 1958), hal. 376.

${ }^{15}$ Sebagaimana dikutip al-Kabisi dengan merujuk pada karya al-Qalyubi, Hasyiyatu al-Qalyubi ala syarh al-muhalla li al-Minhaj.

${ }^{16}$ Ibn Qudamah, Al-Mughni Wa al-Syarh al-Kabir, jil. 6. (Beirut: Dar al-Kutub al-'Arabi, 1972), hal. 185.

${ }^{17}$ Undang-undang Nomor 41 Tahun 2004 tentang wakaf pasal 1 ayat 1. 
Dari beberapa definisi wakaf tersebut, dapat disimpulkan bahwa wakaf bertujuan untuk memberikan manfaat atau faedah harta yang diwakafkan kepada orang yang berhak dan dipergunakan sesuai dengan ajaran syariah Islam. Hal ini sesuai dengan fungsi wakaf yang disebutkan pasal 5 UU No. 41 tahun 2004 yang menyatakan wakaf berfungsi untuk mewujudkan potensi dan manfaat ekonomis harta benda wakaf untuk kepentingan ibadah dan untuk memajukan kesejahteraan umum.

\section{Dasar Hukum Wakaf dalam Al-Quran dan Hadis}

Secara umum tidak terdapat ayat al-Quran yang menerangkan konsep wakaf secara konkrit tekstual. Wakaf termasuk infaq fi sabilillah, maka dasar yang digunakan para ulama dalam menerangkan konsep wakaf ini didasarkan pada keumuman ayat-ayat al-Quran yang menjelaskan tentang infaq $f i$ sabilillah. Di antara ayat-ayat tersebut antara lain:

$$
\begin{aligned}
& \text { مثل الذين ينفقون أموالهم في سبيل الله كمثل حبة أنبتت سبع سنابل في كل سنبلة مئة حبة } \\
& \text { والله يضاعف لمن يشاء والله واسع عليم. الذين ينفقون أموالهم في سبيل الله ثم لا يتبعون ما } \\
& \text { أنفقوا منا ولا أذى لهم أجرهم عند ربهم ولا خوف عليهم ولا هم يحزنون }
\end{aligned}
$$

"Perumpamaan (nafkah yang dikeluarkan oleh) orang-orang yang menafkahkan hartanya di jalan Allah adalah serupa dengan sebutir benih yang menumbuhkan tujuh bulir, pada tiap-tiap bulir: seratus biji. Allah melipat gandakan (ganjaran) bagi siapa yang Dia kehendaki. Dan Allah Maha Luas (karunia-Nya) lagi Maha Mengetahui. Orang-orang yang menafkahkan hartanya di jalan Allah, kemudian mereka tidak mengiringi apa yang dinafkahkannya itu dengan menyebut-nyebut pemberiannya dan dengan tidak menyakiti (perasaan si penerima), mereka memperoleh pahala di sisi Tuhan mereka. Tidak ada kekhawatiran terhadap mereka dan tidak (pula) mereka bersedih hati. (Q.S. al-Baqarah (2): 261-262).

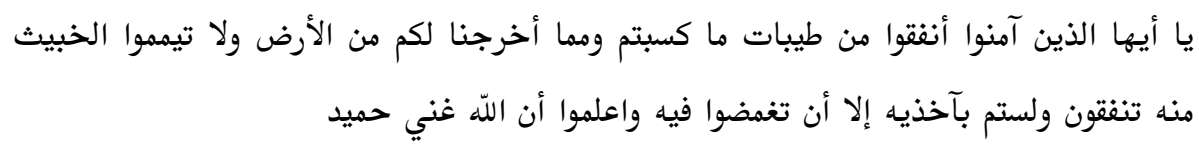

"Hai orang-orang yang beriman, nafkahkanlah (di jalan Allah) sebagian dari hasil usahamu yang baik-baik dan sebagian dari apa yang Kami keluarkan dari bumi untuk kamu. Dan janganlah kamu memilih yang buruk-buruk lalu kamu nafkahkan daripadanya, padahal kamu sendiri tidak mau mengambilnya melainkan dengan memicingkan mata terhadapnya. Dan ketahuilah, bahwa Allah Maha Kaya lagi Maha Terpuji.” (Q.S. al-Baqarah (2): 267).

$$
\text { لن تنالوا البر حتى تنفقوا مما تحبون وما تنفقوا من شيء فإن الله به عليم }
$$


"Kamu sekali-kali tidak sampai kepada kebajikan (yang sempurna) sebelum kamu menafkahkan sebagian dari apa yang kamu cintai. Dan apa saja yang kamu nafkahkan, maka sesungguhnya Allah mengetahuinya” (Q.S. Ali Imran (3): 92)

Ayat-ayat tersebut di atas menjelaskan tentang anjuran untuk menginfakkan harta yang diperoleh untuk mendapatkan pahala dan kebaikan. Di samping itu, ayat 261 surat al-Baqarah telah menyebutkan pahala yang berlipat ganda yang akan diperoleh orang yang menginfakkan hartanya di jalan Allah.

Di antara hadis yang menjadi dasar dan dalil wakaf adalah hadis yang menceritakan tentang kisah Umar bin al-Khaththab ketika memperoleh tanah di Khaibar. Setelah ia meminta petunjuk Nabi tentang tanah tersebut, Nabi menganjurkan untuk menahan asal tanah dan menyedekahkan hasilnya. Hadis tentang hal ini adalah

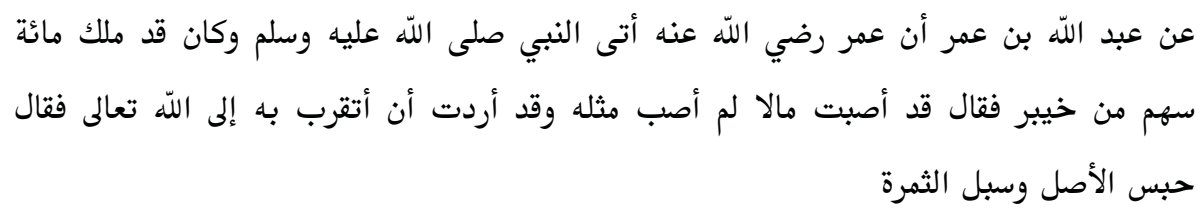

"Dari Abdullah bin Umar bahwa sesungguhnya Umar bin Khattab mendatangi Nabi SAW, (pada waktu itu) Umar baru saja memperoleh 100 kavling tanah Khaibar (yang terkenal subur), maka Umar berkata, 'Saya telah memiliki harta yang tidak pernah saya miliki sebelumnya dan saya benar-benar ingin mendekatikan diri kepada Allah SWT melalui harta ini.' Maka Rasulullah SAW bersabda, 'Tahanlah asal harta tersebut dan alirkan manfaatnya'. (H.R. al-Bukhari, Muslim, al-Tarmidzi, dan al Nasa'i).

Hadis lain yang menjelaskan wakaf adalah hadis yang diceritakan oleh Imam Muslim dari Abu Hurairah sebagai berikut:

$$
\text { اذا مات الانسان انقطع عمله الا من ثلاث صدقة جارية أو علم ينتفع به أو ولد صالح يدعو له }
$$

“Apabila seorang manusia itu meninggal dunia, maka terputuslah amal perbuatannya kecuali dari tiga sumber, yaitu sedekah jariah (wakaf), ilmu pengetahuan yang bisa diambil manfaatnya, dan anak soleh yang mendoakannya." (H.R. Muslim, al-Tirmidzi, al-Nasa' i, dan Abu Daud).

Selain dasar dari al-Quran dan Hadis di atas, para ulama sepakat (ijma') menerima wakaf sebagai satu amal jariah yang disyariatkan dalam Islam. Tidak ada orang yang dapat menafikan dan menolak amalan wakaf dalam Islam karena wakaf 
telah menjadi amalan yang senantiasa dijalankan dan diamalkan oleh para sahabat Nabi dan kaum Muslimin sejak masa awal Islam hingga sekarang. ${ }^{18}$

\section{Sejarah Wakaf Tunai}

Perilaku sejenis wakaf telah dikenal umat manusia sebelum Islam datang. Umat manusia -terlepas dari agama dan kepercayaan yang mereka anut-sesungguhnya telah mengenal beberapa bentuk praktik pendayagunaan harta benda, yang substansinya tidak jauh berbeda dengan wakaf dalam Islam. Hal ini disebabkan pada dasarnya, umat manusia sudah menyembah Tuhan melalui ritual keagamaan sesuai kepercayaan mereka. Hal inilah yang kemudian menjadi faktor pendorong bagi setiap umat beragama untuk mendirikan bangunan peribadatannya masing-masing. ${ }^{19}$

Mereka yang memiliki kepedulian serta perhatian terhadap kelangsungan agamanya rela melepaskan sebagian tanahnya atau menyumbangkan sebagian harta miliknya untuk kepentingan rumah peribadatan. Contoh yang paling nyata dari adanya praktik wakaf sebelum Islam adalah dibangunnya al-Ka'bah al-Musyarrafah oleh Nabi Ibrahim as. Hanya saja, dalam perjalanan waktu, Ka'bah pernah digunakan sebagai tempat penyembahan berhala, padahal sebelumnya adalah tempat beribadah kepada Allah Swt. ${ }^{20}$

Jika praktik wakaf telah dikenal sebelum Islam, maka yang membedakannya dengan wakaf dalam Islam adalah bahwa praktik wakaf yang diamalkan masyarakat jahiliyah dilakukan semata-mata hanya untuk mencari prestise (kebanggan). Sedangkan dalam Islam bertujuan untuk mencari ridla Allah dan sebagai sarana mendekatkan diri kepada-Nya. ${ }^{21}$

Dalam sejarah Islam, wakaf dikenal sejak masa Rasulullah SAW karena wakaf disyariatkan pada tahun kedua Hijriyah. Ada dua pendapat yang berkembang di kalangan ahli yurisprudensi Islam (fuqaha) tentang siapa yang pertama kali melaksanakan syariat wakaf. Menurut sebagian pendapat ulama mengatakan bahwa yang pertama kali melaksanakan wakaf adalah Rasulullah SAW yaitu wakaf tanah milik Nabi SAW untuk dibangun masjid. ${ }^{22}$ Sebagian ulama menyatakan bahwa yang pertama

${ }^{18}$ Wakaf disyariatkan pada tahun ke-2 Hijriyah. Sebagian ulama berpendapat bahwa pelaksanaan wakaf pertama dilakukan oleh Umar ibn Khaththab terhadap tanahnya yang terletak di Khaibar, sebagian lain berpendapat bahwa pelaksanaan wakaf pertama dilakukan oleh Rasulullah SAW untuk dibangun masjid. Ismail bin Umar bin Kasir, Tafsir Ibnu Katsir, (Riyad: Dar al-Salam, 2001), Juz I, hal. 381; Sayyid Sabiq, Fiqh al-Sunnah, Beirut: Dar al-Fikr, 1983); Imam Muhammad bin Ismail alKahlani, Subul al-Salam. (Bandung: Maktabah Dahlan, tt.), hal. 87.

${ }^{19}$ Al-Kabisi, op.cit., hal. 13.

${ }^{20}$ Ibid., hal. 14

${ }^{21}$ Sebagaimana dikutip Al-Kabisi dari Syarh Minah al-Jalil ala Mukhtashar Khalil, karya Muhammad Ahmad Alisy, Mesir: Penerbit al-Kubra, 1294H, jilid 3, h. 35.

${ }^{22}$ Lihat Habib Ahmed, Role of Zakah and Awqaf in Poverty Alleviation. (Jeddah: IRTI, 2004), hal. 30 . 
kali melaksanakan syariat wakaf adalah Umar bin Khatab. Pendapat ini berdasarkan hadits yang diriwayatkan Ibnu Umar ra, sebagaimana telah dikemukakan di atas.

Praktek wakaf juga berkembang luas pada masa dinasti Umayah dan dinasti Abbasiyah dan dinasti sesudahnya, banyak orang berduyun-duyun untuk melaksanakan wakaf, dan wakaf tidak hanya untuk orang-orang fakir dan miskin saja, tetapi wakaf menjadi modal untuk membangun lembaga pendidikan, membangun perpustakaan dan membayar gaji para statnya, gaji para guru dan beasiswa untuk para siswa dan mahasiswa. Antusiasme masyarakat kepada pelaksanaan wakaf telah menarik perhatian negara untuk mengatur pengelolaan wakaf sebagai sektor untuk membangun solidaritas sosial dan ekonomi masyarakat.

Wakaf tunai (cash waqf) pertama kali dipakai pada masa Utsman di Mesir, di akhir abad ke-16 (1555-1823 M). ${ }^{23}$ Pada era Utsmani di Mesir, berkembang pemakaian fikih Hanafi dalam menjalankan aktivitas binis dan sosialnya. Imam Muhammad asy-Syaibani menjelaskan bahwa sekalipun tidak ada dukungan hadis yang kuat, penggunaan harta bergerak sebagai wakaf dibolehkan, jika memang hal itu sudah menjadi kebiasaan umum pada daerah tertentu. Bahkan bagi Imam Muhammad alSarakhsi, kebiasaan umum tidak selalu menjadi persyaratan dalam penggunaan harta bergerak sebagai harta wakaf. Bahkan menurut Crecelius, Dia menyatakan: ${ }^{24}$

"No Islamic State was more energetic in its production of statistical records, more systematic in its record keeping, and more assiduous in preserving these records than the Ottoman Empire."

Artinya: " Tidak ada negara Islam yang lebih energik dalam menghasilkan wakaf dan catatan statistiknya, lebih sistematis dalam menjaga catatan tersebut, serta lebih ketat dalam mengawasi catatan tersebut ketimbang Dinasti Ustman.”

Terdapat tigas alasan mendasar kenapa ahli fiqh era Utsmani menyusun bangunan wakaf tunai: pertama, pandangan bahwa aset bergerak dapat menjadi harta wakaf. Kedua, penilaian dan penerimaan atas uang sebagai aset bergerak. Ketiga, persetujuan atas pemberian uang tunai.

Berikut bentuk uang wakaf tunai pada era Ustman di Mesir:

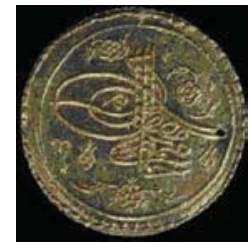

${ }^{23}$ Murat Cizakca, Ottoman Cash Waqfs Revisited: The Case of Bursa 1555-1823, UK: FSTC, 2004, hal. 1.

${ }^{24}$ Crecelius, Daniel, "Introduction," Journal of the Economic and Social History of the Orient, Leiden:E.J.Brill, v.38, part 3 (august), 1995, hal. 247. 


\section{Gambar 1. Uang Wakaf pada Era Utsman}

(sumber: Murat Cizakca, UK: FSTC, 2004)

Kepopuleran wakaf tunai terjadi setelah Professor Mannan mensosialisasikannya di Bangladesh melalui Social Investment Bank Limited (SIBL). ${ }^{25}$ SIBL membuat Sertifikat wakaf tunai (Cash Waqf Certificate) untuk mengumpulkan dana dari orang kaya dan membagi perolehan wakaf tunai yang telah dikumpulkannya kepada orang-orang miskin. Popularitas "wakaf tunai", ditimbulkan karena fleksibilitas penyebaran manfaat wakaf tunai kepada kalangan mustadh'afin (orang fakir dan orang yang tertindas ekonominya) dan $d h u^{\prime} a f a^{\prime}$ (orang miskin) di segala tempat.

\section{Wakaf dalam Hukum Positif Indonesia}

Dalam konteks negara Indonesia, praktik wakaf sudah dilaksanakan oleh masyarakat muslim Indonesia sejak sebelum merdeka. Pemerintah Indonesia pun telah menetapkan Undang-undang khusus yang mengatur tentang perwakafan di Indonesia, yaitu Undang-undang Nomor 41 tahun 2004 tentang Wakaf. Untuk melengkapi Undang-undang tersebut, pemerintah juga telah menetapkan Peraturan Pemerintah Nomor 42 tahun 2006 tentang Pelaksanaan Undang-undang Nomor 41 tahun 2004.

Sebelum itu, telah ada berbagai peraturan yang mengatur tentang wakaf. $^{26}$ Peraturan yang mengatur tentang wakaf adalah UU No. 5 Tahun 1960 tentang Peraturan Dasar Pokok-pokok Agraria, khususnya pasal 5, 14 (1), dan 49, PP No. 28 Tahun 1977 tentang Perwakafan Tanah Milik, Peraturan Menteri No. 1 Tahun 1978 tentang Peraturan Pelaksanaan PP No. 28 Tahun 1977, Intruksi Bersama Menag RI dan Kepala BPN No. 4 Tahun 1990 tentang Sertifikat Tanah Wakaf, Badan Pertanahan Nasional No. 630.1-2782 tantang Pelaksanaan Penyertifikatan Tanah Wakaf, Inpres No. 1 Tahun 1991 tentang KHI, SK Direktorat BI No. 32/34/KEP/DIR tentang Bank Umum Berdasarkan Prinsip Syariah (pasal 29 ayat 2 berbunyi: bank dapat bertindak sebagai lembaga baitul mal, yaitu menerim dana yang berasal dari zakat, infaq, shadaqah, wakaf, hibah, atau dana sosial lainnya dan menyalurkannya kepada yang berhak dalam bentuk santunan dan atau pinjaman kebajikan [qard al-hasan]), SK Direktorat BI No. 32/36/KEP/DIR tentang Bank Perkreditan Rakyat Berdasarkan Prinsip Syariah (pasal 28 berbunyi: BPRS dapat bertindak sebagai lembaga baitul mal, yaitu menerim dana yang berasal dari zakat, infaq, shadaqah, wakaf, hibah, atau dana social lainnya dan menyalurkannya kepada yang berhak dalam bentuk santunan dan atau pinjaman kebajikan [qard al-hasan]). ${ }^{27}$

${ }^{25}$ Dian Masyita, Muhammad Tasrif, dan Abdi Suryadinata Telaga, "A Dynamic Model for Cash Waqf Management as One of The Alternative Instruments for the Poverty Alleviation in Indonesia," hal. 1 diakses dari http://www.islamic-world.net.

${ }^{26}$ Lihat DEPAG RI, Peraturan Perundangan Perwakafan. (Jakarta: DEPAG RI, 2006)

${ }^{27}$ Elsi Kartika Sari, Pengantar Hukum Zakat dan Wakaf. (Jakarta: Grasindo, 2006), hlm. 57-59. 
Berdasarkan penjelasan di atas, perlu dipaparkan di sini mengenai konsepsi fiqh wakaf Indonesia, yang memiliki persamaan dan perbedaan dengan fikih tradisional. Di Indonesia, rukun wakaf dalam hukum fiqh ada empat yaitu:

(1) orang yang berwakaf (al-waqif).

(2) benda yang diwakafkan (al-mauquf).

(3) orang yang menerima manfaat wakaf (al-mauquf'alaibi/nadzir).

(4) lafadz atau ikrar wakaf (sighah).

Sedangkan dalam UU Wakaf Pasal 6 yang merupakan fiqh Indonesia yang telah diundangkan, selain 4 rukun tersebut, wakaf dilaksanakan dengan memenuhi 6 unsur, yaitu 4 unsur tersebut ditambah dengan dua unsur lain yaitu: peruntukan harta benda wakaf dan jangka waktu wakaf.

Dalam konteks ini, wakif meliputi perseorangan, organisasi, maupun badan hukum. Wakif perseorangan dapat melakukan wakaf apabila memenuhi persyaratan: dewasa, berakal sehat, tidak terhalang melakukan perbuatan hukum, dan merupakan pemilik sah harta benda wakaf. Wakif organisasi dan badan hukum dapat melakukan wakaf apabila memenuhi ketentuan organisasi atau badan hukum untuk mewakafkan harta benda wakaf milik organisasi atau badan hukum sesuai dengan anggaran dasar organisasi atau badan hukum yang bersangkutan. ${ }^{28}$

Adapun pihak nazhir bisa dilakukan oleh perseorangan, organisasi, atau badan hukum. Syarat nazhir perseorangan adalah warga negara Indonesia, beragama Islam dewasa, amanah, mampu secara jasmani dan rohani, dan tidak terhalang melakukan perbuatan hukum. Organisasi atau badan hokum yang bisa menjadi nazhir harus memenuhi persyaratan yaitu pengurus organisasi atau badan hukum yang bersangkutan memenuhi persyaratan nazhir perseorangan sebagaimana tersebut di atas, organisasi atau badan hukum itu bergerak di bidang sosial, pendidikan, kemasyarakatan, dan/atau keagamaan Islam, badan hukum itu dibentuk sesuai dengan peraturan perundangundangan yang berlaku di Indonesia.

Tugas nazhir adalah melakukan pengadministrasian harta benda wakaf, mengelola dan mengembangkan harta benda wakaf sesuai dengan tujuan, fungsi, dan peruntukannya, mengawasi dan melindungi harta benda wakaf, melaporkan pelaksanaan tugas kepada Badan Wakaf Indonesia. Dalam melaksanakan tugas tersebut, nazhir dapat menerima imbalan dari hasil bersih atas pengelolaan dan pengembangan harta benda wakaf yang besarnya tidak melebihi $10 \%$ (sepuluh persen). ${ }^{29}$

Syarat-syarat harta yang diwakafkan (al-mauquf) harus memenuhi beberapa persyaratan, yaitu: al-mauquf harus barang yang berharga, al-mauquf harus diketahui kadarnya, al-mauquf dimiliki oleh wakif secara sah, al-mauquf harus berdiri sendiri, tidak melekat kepada harta lain (mufarrazan). Harta benda wakaf bisa berbentuk benda

\footnotetext{
${ }^{28}$ UU wakaf bagian keempat.

${ }^{29} \mathrm{UU}$ wakaf bagian kelima, pasal 9-12
} 
tidak bergerak ataupun benda bergerak. Yang termasuk benda tidak bergerak antara lain:

a. hak atas tanah sesuai dengan ketentuan peraturan perundang-undangan yang berlaku baik yang sudah maupun yang belum terdaftar;

b. bangunan atau bagian bangunan yang berdiri di atas tanah sebagaimana dimaksud pada huruf a;

c. tanaman dan benda lain yang berkaitan dengan tanah;

d. hak milik atas satuan rumah susun sesuai dengan ketentuan peraturan perundang-undangan yang berlaku;

e. benda tidak bergerak lain sesuai dengan ketentuan syariah dan peraturan perundang-undangan yang berlaku.

Sedangkan yang dimaksud benda bergerak adalah harta benda yang tidak bisa habis karena dikonsumsi, antara lain:

a. uang;

b. logam mulia;

c. surat berharga;

d. kendaraan;

e. hak atas kekayaan intelektual;

f. hak sewa; dan

g. benda bergerak lain sesuai dengan ketentuan syariah dan peraturan perundangundangan yang berlaku. ${ }^{30}$

Berdasarkan paparan tersebut, dapat ditegaskan bahwa pemahaman tentang benda wakaf hanya sebatas benda tak bergerak, seperti tanah adalah kurang tepat. Karena wakaf juga bisa berupa benda bergerak, antara lain uang, logam mulia, surat berharga, kendaraan, hak kekayaan intelektual, dan hak sewa, sebagaimana tercermin dalam Bab II, Pasal 16, UU No. 41 tahun 2004, dan juga sejalan dengan fatwa MUI ihwal bolehnya wakaf uang.

Syarat-syarat shigah berkaitan dengan ikrar wakaf, yaitu harus memuat nama dan identitas Wakif, nama dan identitas Nazhir, keterangan harta benda wakaf, dan peruntukan harta benda wakaf, serta jangka waktu wakaf.

Pada prinsipnya, dalam rangka mencapai tujuan dan fungsi wakaf, harta benda wakaf hanya dapat diperuntukan bagi:

a. sarana dan kegiatan ibadah;

b. sarana dan kegiatan pendidikan serta kesehatan;

c. bantuan kepada fakir miskin, anak terlantar, yatim piatu, bea siswa;

d. kemajuan dan peningkatan ekonomi umat; dan/atau

e. kemajuan kesejahteraan umum lainnya yang tidak bertentangan dengan syariah dan peraturan perundang-undangan.

${ }^{30}$ Bagian keenam pasal 15-16. 
Di Indonesia, kegiatan wakaf dikenal seiring dengan perkembangan dakwah Islam di Nusantara. Di samping melakukan dakwah Islam, para ulama juga sekaligus memperkenalkan ajaran wakaf. Hal ini terbukti dari banyaknya masjid-masjid yang bersejarah dibangun di atas tanah wakaf. Ajaran wakaf ini terus berkembang di bumi Nusantara, baik pada masa dakwah pra kolonial, masa kolonial, maupun pasca kolonial pada masa Indonesia merdeka.

Hal ini terlihat dari kenyataan bahwa lembaga wakaf yang berasal dari agama Islam ini telah diterima (diresepsi) menjadi hukum adat bangsa Indonesia sendiri. Masa pemerintahan kolonial merupakan momentum kegiatan wakaf. Karena pada masa itu, perkembangan organisasi keagamaan, sekolah, madrasah, pondok pesantren, masjid, semuanya merupakan swadaya dan berdiri di atas tanah wakaf. Namun, perkembangan wakaf kemudian hari tak mengalami perubahan yang berarti. Kegiatan wakaf dilakukan terbatas untuk kegiatan keagamaan, seperti pembangunan masjid, mushalla, langgar, madrasah, perkuburan, sehingga kegiatan wakaf di Indonesia kurang bermanfaat secara ekonomis bagi rakyat banyak.

Walaupun beberapa aturan telah dibuat oleh pemerintah terkait dengan mekanisme wakaf, seperti PP Nomor 28 Tahun 1977 tentang perwakafan tanah milik, akan tetapi PP ini hanya mengatur wakaf pertanahan saja. Ini berarti tak jauh beda dengan model wakaf pada periode awal, identik dengan wakaf tanah, dan kegunaannya pun terbatas pada kegiatan sosial keagamaan, seperti masjid, kuburan, madrasah, dan lain-lain.

Karena minimnya regulasi yang mengatur tentang perwakafan, maka tidaklah heran jika perkembangan wakaf di Indonesia mengalami stagnasi. Stagnasi perkembangan wakaf di Indonesia mulai mengalami dinamisasi ketika pada tahun 2001, beberapa praktisi ekonomi Islam mulai mengusung paradigma baru ke tengah masyarakat mengenai konsep baru pengelolaan wakaf tunai untuk peningkatan kesejahteraan umat. Ternyata konsep tersebut menarik dan mampu memberikan energi untuk menggerakkan kemandegan perkembangan wakaf. Kemudian pada tahun 2002, Majelis Ulama Indonesia (MUI) menyambut konsep tersebut dengan mengeluarkan fatwa yang membolehkan wakaf uang (waqf al-nuqud).

Fatwa MUI tersebut kemudian diperkuat oleh hadirnya UU No. 41/2004 tentang wakaf yang menyebutkan bahwa wakaf tidak hanya benda tidak bererak, tetapi juga dapat berupa benda bergerak, seperti uang. Selain itu, diatur pula kebijakan perwakafan di Indonesia, mulai dari pembentukan nazhir sampai dengan pengelolaan harta wakaf. Untuk dapat menjalankan fungsinya, UU ini masih memerlukan perangkat lain yaitu Peraturan Pemerintah dan Peraturan Menteri Agama tentang Wakaf Uang yang akan menjadi juklak dalam implementasinya, serta adanya Badan Wakaf Indonesia (BWI) yang akan berfungsi sebagai sentral nazhir wakaf. Setelah melalui proses panjang, pada penghujung tahun 2006 terbitlah PP No. 42/2006 tentang Pelaksanaan UU Wakaf. Setelah itu, pada juli 2007 keluar Keputusan Presiden 
Republik Indonesia nomor 75/M tahun 2007 yang memutuskan dan mengangkat keanggotaan BWI periode 2007-2010. ${ }^{31}$

Dengan demikian, ternyata dalam perjalanan sejarahnya, wakaf terus berkembang dan insyaAllah akan selalu berkembang bersamaan dengan laju perubahan zaman dengan berbagai inovasi-inovasi yang relevan dengan tetap mengedepankan dan berpandukan prinsip Syariah. Lahirnya UU wakaf berikut peraturan turunannya merupakan titik tolak peningkatan pemberdayaan potensi wakaf di Indonesia ke arah yang lebih produktif dalam bingkai fiqh Indonesia.

Berdasarkan paparan tersebut, dapat ditegaskan bahwa pemahaman tentang pemanfaatan harta benda wakaf yang selama ini masih terbatas digunakan untuk tujuan ibadah saja (yang berwujud misalnya: pembangunan masjid, komplek kuburan, panti asuhan, dan pendidikan) adalah kurang tepat. Nilai ibadah itu tidak harus berwujud langsung seperti itu. Bisa saja, di atas lahan wakaf dibangun pusat perbelanjaan, yang keuntungannya nanti dialokasikan untuk beasiswa anak-anak yang tidak mampu, layanan kesehatan gratis, atau riset ilmu pengetahuan untuk meningkatkan kesejahteraan masyarakat. Ini juga bagian dari ibadah.

\section{Permasalahan Wakaf di Indonesia}

Menurut Uswatun, ${ }^{32}$ terdapat beberapa faktor yang menyebabkan wakaf di Indonesia belum berperan dalam memberdayakan ekonomi umat:

1. Masalah Pemahaman Masyarakat tentang Hukum Wakaf.

Selama ini, umat Islam masih banyak yang beranggapan bahwa aset wakaf itu hanya boleh digunakan untuk tujuan ibadah saja. Misalnya, pembangunan masjid, komplek kuburan, panti asuhan, dan pendidikan. Padahal, nilai ibadah itu tidak harus berwujud langsung seperti itu. Bisa saja, di atas lahan wakaf dibangun pusat perbelanjaan, yang keuntungannya nanti dialokasikan untuk beasiswa anak-anak yang tidak mampu, layanan kesehatan gratis, atau riset ilmu pengetahuan. Ini juga bagian dari ibadah.

Selain itu, pemahaman ihwal benda wakaf juga masih sempit. Harta yang bisa diwakafkan masih dipahami sebatas benda tak bergerak, seperti tanah. Padahal wakaf juga bisa berupa benda bergerak, antara lain uang, logam mulia, surat berharga, kendaraan, hak kekayaan intelektual, dan hak sewa. Ini sebagaimana tercermin dalam Bab II, Pasal 16, UU No. 41 tahun 2004, dan juga sejalan dengan fatwa MUI ihwal bolehnya wakaf uang. ${ }^{33}$

2. Pengelolaan dan Manajemen Wakaf.

${ }^{31}$ Tholhah Hasan (2009), "Perkembangan Kebijakan Wakaf di Indonesia”, dalam Republika, Rabu, 22 April 2009, accessed 3 Juli 2009.

${ }^{32}$ Uswatun, op.cit., hal. 17-18.

${ }^{33}$ Abdullah Ubaid Matraji (Staf Divisi Humas Badan Wakaf Indonesia), Republika Newsroom, Kamis, 05 Februari 2009, accessed 3 Juli 2009. 
Saat ini pengelolaan dan manajemen wakaf di Indonesia masih memprihatinkan. Sebagai akibatnya cukup banyak harta wakaf terlantar dalam pengelolaannya, bahkan ada harta wakaf yang hilang. Salah satu penyebabnya adalah umat Islam pada umumnya hanya mewakafkan tanah dan bangunan sekolah, dalam hal ini wakif kurang memikirkan biaya operasional sekolah, dan nazhirnya kurang profesional. Oleh karena itu, kajian mengenai manajemen pengelolaan wakaf sangat penting. Kurang berperannya wakaf dalam memberdayakan ekonomi umat di Indonesia karena wakaf tidak dikelola secara produktif. Untuk mengatasi masalah ini, wakaf harus dikelola secara produktif dengan menggunakan manajemen modern. Untuk mengelola wakaf secara produktif, ada beberapa hal yang perlu dilakukan sebelumnya. Selain memahami konsepsi fikih wakaf dan peraturan perundang-undangan, nazhir harus profesional dalam mengembangkan harta yang dikelolanya, apalagi jika harta wakaf tersebut berupa uang. Di samping itu, untuk mengembangkan wakaf secara nasional, diperlukan badan khusus yang menkoordinasi dan melakukan pembinaan nazhir. Pada saat di Indonesia sudah dibentuk Badan Wakaf Indonesia.

3. Benda yang Diwakafkan dan Nazhir (pengelola wakaf).

Pada umumnya tanah yang diwakafkan umat Islam di Indonesia hanyalah cukup untuk membangun masjid atau mushalla, sehingga sulit untuk dikembangkan. Memang ada beberapa tanah wakaf yang cukup luas, tetapi nazhir tidak profesional. Di Indonesia masih sedikit orang yang mewakafkan harta selain tanah (benda tidak bergerak), padahal dalam fikih, harta yang boleh diwakafkan sangat beragam termasuk surat berharga dan uang. Dalam perwakafan, salah satu unsur yang amat penting adalah nazhir. Berfungsi atau tidaknya wakaf sangat tergantung pada kemampuan nazhir. Di berbagai negara yang wakafnya dapat berkembang dan berfungsi untuk memberdayakan ekonomi umat, wakaf dikelola oleh nazhir yang profesional. Di Indonesia masih sedikit nazhir yang profesional, bahkan ada beberapa nazhir yang kurang memahami hukum wakaf, termasuk kurang memahami hak dan kewajibannya. Dengan demikian, wakaf yang diharapkan dapat memberi kesejahteraan pada umat, tetapi sebaliknya justru biaya pengelolaannya terus-menerus tergantung pada zakat, infaq dan shadaqah dari masyarakat. Di samping itu, dalam berbagai kasus ada sebagian nazhir yang kurang memegang amanah, seperti melakukan penyimpangan dalam pengelolaan, kurang melindungi harta wakaf, dan kecurangan-kecurangan lain, sehingga memungkinkan wakaf tersebut berpindah tangan. Untuk mengatasi masalah ini, hendaknya calon wakif sebelum berwakaf memperhatikan lebih dahulu apa yang diperlukan masyarakat, dan dalam memilih nazhir sebaiknya mempertimbangkan kompetensinya. ${ }^{34}$

${ }^{34}$ Uswatun Hasanah, op.cit., hal. 18. 


\section{Pemberdayaan Wakaf Tunai di Indonesia}

Wakaf pada dasarnya adalah "economic corporation", sehingga wakaf merupakan kegiatan yang mengandung unsur investasi masa depan dan mengembangkan harta produktif ${ }^{35}$ untuk generasi yang akan datang sesuai dengan tujuan wakaf, baik berupa pelayanan maupun pemanfaatan hasilnya secara langsung. ${ }^{36}$ Bentuk-bentuk wakaf yang sudah dikemukakan tersebut merupakan bagian atau unit dana investasi. Investasi adalah landasan utama bagi pengembangan ekonomi. Investasi sendiri memiliki arti mengarahkan sebagian dari harta yang dimiliki oleh seseorang untuk membentuk modal produksi, yang mampu menghasilkan manfaat/barang dan dapat digunakan untuk generasi mendatang. Investasi yang dimaksud berupa investasi yang kepemilikan dan tujuannya mampu menghasilkan keuntungan yang direncanakan secara ekonomi dan hasilnya disalurkan untuk mereka yang ditentukan oleh wakif dalam ikrar wakaf. Dengan demikian, dapat dikatakan bahwa secara ekonomi, wakaf (Islam) adalah membangun harta produktif melalui kegiatan investasi untuk kepentingan mereka yang memerlukan yang telah ditetapkan dalam ikrar wakaf. Dengan demikian, hasil atau produk harta wakaf dapat dibedakan menjadi dua bagian. Pertama, wakaf langsung, yaitu harta wakaf yang menghasilkan pelayanan berupa barang untuk dikonsumsi langsung oleh orang yang berhak atas wakaf, seperti rumah sakit, sekolah, rumah yatim piatu, dan pemukiman. Kedua, wakaf produktif, yaitu wakaf yang dikelola untuk tujuan investasi dan produksi barang dan jasa pelayanan yang diperbolehkan menurut hukum Islam. Dalam bentuk ini, modalnya (harta wakaf) diinvestasikan, kemudian hasil investasi tersebut didistribusikan kepada mereka yang berhak. ${ }^{37}$

Wakaf merupakan salah satu lembaga sosial ekonomi Islam yang potensinya belum sepenuhnya digali dan dikembangkan. Akan tetapi akhir-akhir ini upaya untuk mengembangkan potensi wakaf ini terus menerus dilakukan melalui berbagai pengkajian, baik dari segi peranannya dalam sejarah, maupun kemungkinan peranannya di masa yang akan datang. Cukup banyak pemikir-pemikir Islam khususnya pakar hukum Islam dan ekonomi Islam, seperti Monzer Kahf, Khaled R. Al-Hajeri, dan Abdulkader Thomas, M.A. Mannan, melakukan pengkajian tentang wakaf. Pengkajian tentang wakaf ini tidak hanya terjadi di universitas-universitas Islam, tetapi juga di Harvard University.

${ }^{35}$ Diperlukan strategi untuk "menyulap" aset wakaf agar bernilai produktif. Aset wakaf yang berupa tanah, untuk memproduktifkan, bisa dilakukan dengan: lihat dulu lokasinya: stategis atau tidak. Jika tidak, maka lebih baik ditukargulingkan. Setelah dinilai strategis, tinggal melihat areanya di mana? Kalau tanah di pedesaan, jenis usaha produktif yang cocok antara lain perkebunan, pertanian, dan perikanan. Sedang tanah di perkotaan dapat dimanfaatkan dengan membangun pusat perbelanjaan, apartemen, rumah sakit, atau pom bensin. Kalau lokasinya di pantai? Bisa saja dikelola jadi obyek wisata, tambak ikan, atau bisa juga perkebunan di rawa bakau. Aset wakaf yang berupa benda bergerak, uang. sebagai modal, dan menyalurkan keuntungan pengelolaan untuk kesejahteraan masyarakat.

${ }^{36}$ Munzir Kahaf, Manajemen Wakaf Produktif, diterjemahkan oleh Muhyiddin Mas Rida, (Jakarta: Khlmifa, 2005) hal. 59

${ }^{37}$ Ibid., hal. 60-61. 
Jika para nazhir (pengelola wakaf) di Indonesia mau dan mampu bercermin pada pengelolaan wakaf yang sudah dilakukan oleh berbagai negara seperti Mesir, Bangladesh dan lain-lain, insyaAllah hasil pengelolaan wakaf di Indonesia dapat dipergunakan untuk mengatasi berbagai permasalahan sosial dan ekonomi yang ada saat ini dan masih dihadapi oleh sebagian bangsa Indonesia, seperti kemiskinan, pengangguran, dan masalah sosial lainnya. Apalagi jika wakaf yang diterapkan di Indonesia tidak dibatasi pada benda tidak bergerak saja, tetapi juga benda bergerak, termasuk uang. ${ }^{38}$

Pada tanggal 11 Mei 2002 Komisi Fatwa Majelis Ulama Indonesia telah menetapkan fatwa tentang wakaf uang, yang isinya adalah sebagai berikut.

1. Wakaf uang (Cash Wakaf/Waqf al-Nuqud) adalah wakaf yang dilakukan seseorang, kelompok orang, lembaga atau badan hukum dalam bentuk uang tunai.

2. Termasuk ke dalam pengertian uang adalah surat-surat berharga.

3. Wakaf uang hukumnya jawaz (boleh).

4. Wakaf uang hanya boleh disalurkan dan digunakan untuk hal-hal yang dibolehkan secara syar'i.

5. Nilai pokok wakaf uang harus dijamin kelestariannya, tidak boleh dijual, dihibahkan, dan atau diwariskan.

Dengan demikian, intinya wakaf uang atau kadang disebut dengan wakaf tunai adalah wakaf berupa uang dalam bentuk rupiah yang dapat dikelola secara produktif, hasilnya dimanfaatkan untuk mauquf 'alaih. Ini berarti bahwa uang yang diwakafkan tidak boleh diberikan langsung kepada mauquf alaih, tetapi nazhir harus menginvestasikan lebih dulu, kemudian hasil investasi itulah yang diberikan kepada mauquf'alaih.

Paling tidak, teridentifikasi ada empat manfaat utama dari wakaf uang dewasa ini, yaitu:

${ }^{38}$ Terdapat beberapa pendapat yang memperkuat tentang kebolehan wakaf uang, yaitu: (1) Diriwayatkan oleh Imam Bukhari bahwa Imam az-Zuhri (wafat $124 \mathrm{H}$ ) salah seorang ulama terkemuka dan peletak dasar tadwin al-hadis memfatwakan, dianjurkan wakaf dinar dan dirham untuk pembagunan sarana dakwah, sosial dan pendidikan umat Islam. Adapun caranya dengan menjadikan uang tersebut sebagai modal usaha kemudian menyalurkan keuntungannya sebagai wakaf. Lihat Abu Su'ud Muhammad, Risalah fi Jawazi Waqf al-Nuqud, (Beirut: Dar Ibn Hazm, 1997), hal. 20-21. (2) Mutaqaddimin dari ulama mazhab Hanafi membolehkan wakaf uang dinar dan dirham sebagai pengecualian, atas dasar Istihsan bi al-'Urfi, berdasarkan atsar Abdullah bin Mas'ud r.a: "Apa yang dipandang baik oleh kaum muslimin maka dalam pandangan Allah adalah baik, dan apa yang dipandang buruk oleh kaum muslimin maka dalam pandangan Allah pun buruk". Lihat Wahbah alZuhaili, al-Fiqh al-Islam wa Adillatuhu, juz VIII (Damaskus: Dar al-Fikr, 1985), hal. 162. (3) pendapat sebagian ulama mazhab al-Syafi'i: "Abu Tsyar meriwayatkan dari Imam al-Syafi'i tentang kebolehan wakaf dinar dan dirham (uang)". Lihat al-Mawardi, al-Hawi al-Kabir, juz IX, tahqiq Mahmud Mathraji, (Beirut: Dar al-Fikr,1994), hal. 379. 
1. Wakaf uang jumlahnya bisa bervariasi sehingga seseorang yang memiliki dana terbatas sudah bisa mulai memberikan dana wakafnya tanpa harus menunggu menjadi tuan tanah terlebih dahulu.

2. Melalui wakaf tunai, asset wakaf yang berupa tanah-tanah kosong dapat dimanfaatkan untuk pembangunan gedung atau diolah lahan pertanian.

3. Dana wakaf tunai juga bisa membantu sebagai lembaga pendidikan Islam yang cash flownya terkadang kembang kempis dan menggaji civitas akademika ala kadarnya.

4. Pada gilirannya InsyaAllah umat Islam dapat lebih mandiri dalam mengembangkan dunai pendidikan tanpa harus selalu tergantung pada anggaran pendidikan Negara yang terbatas. ${ }^{39}$

Wakaf uang diharapkan dapat menjadi sarana bagi rekonstruksi sosial dan pembangunan, di mana mayoritas penduduk dapat ikut berpartisipasi. Untuk mewujudkan partisipasi tersebut, maka berbagai upaya pengenalan tentang arti penting wakaf uang sebagai sarana mentransfer tabungan si kaya kepada para usahawan (entrepreneurs) dan anggota masyarakat dalam mendanai berbagai kegiatan di negaranegara Islam perlu dilakukan secara intensif. Mengapa harus wakaf uang? ${ }^{40}$

1. Siapapun Bisa. Kini, orang yang ingin wakaf tidak harus menunggu menjadi kaya. Minimal Rp. 1.000.000 (satu juta rupiah), anda sudah bisa menjadi wakif (orang yang berwakaf), dan mendapat Sertifikat Wakaf Uang.

2. Jaringan Luas. Kapan pun dan di manapun anda bisa setor wakaf uang. Mudah bukan? Sebab, BWI telah bekerjasama dengan Lembaga Keuangan Syariah untuk memudahkan penyetoran.

3. Uang Tak Berkurang. Dana yang diwakafkan, sepeser pun, tidak akan berkurang jumlahnya. Justru sebaliknya, dana itu akan berkembang melalui investasi yan dijamin aman, dengan pengelolaan secara amanah, bertangung jawab, professional, dan transparan.

4. Manfaat Berlipat. Hasil investasi dana itu akan bermanfaat untuk peningkatan prasarana ibadah dan sosial, serta kesejahteraan masyarakat (social benefit).

5. Investasi Akhirat. Manfaat yang berlipat itu menjadi pahala wakif yang terus mengalir, meski sudah meninggal, sebagai bekal di akhirat.

39 Syafii Antonio, "Cash Waqf dan Anggaran Pendidikan", dalam Kumpulan Hasil Seminar Perwakafan. (Jakarta: Depag RI, 2004), hal. 212.

${ }^{40}$ Alur wakaf uang: (1). Wakif datang ke LKS-PWU (2). Mengisi akta Ikrar Wakaf (AIW) dan melampirkan fotokopi kartu identitas diri yang berlaku (3). Wakif menyetor nominal wakaf dan secara otomatis dana masuk ke rekening BWI (4). Wakif Mengucapkan Shighah wakaf dan menandatangani AIW bersama dengan: (a) 2 orang saksi (b) pejabat bank sebagai Pejabat Pembuat AIW (PPAIW) (5). LKS-PWU mencetak Sertifikat Wakaf Uang (SWU) (6). LKS-PWU memberikan AIW dan SWU ke Wakif. Saat ini terdapat 5 Lembaga Keuangan Syariah (LKS) Penerima Wakaf Uang (PWU), yaitu BSM, BMI, BSMI, BNI Syariah, Bank DKI Syariah. 
Wakaf uang membuka peluang yang unik untuk menciptakan investasi guna memberikan pelayanan keagamaan, layanan pendidikan, dan layanan sosial. Tabungan orang-orang kaya dapat dimanfaatkan dengan menukarkannya dengan Cash-Waqf Certificate. Hasil pengembangan wakaf yang diperoleh dari sertifikat tersebut dapat dimanfaatkan untuk tujuan-tujuan yang bermacam-macam seperti tujuan-tujuan wakaf itu sendiri. Kegunaan lain dari Cash-Waqf Certificate adalah bahwa dia dapat mengubah kebiasaan lama di mana kesempatan wakaf seolah-olah hanya untuk orang-orang kaya saja.

Mustafa Edwin Nasution pernah melakukan asumsi bahwa jumlah penduduk Muslim kelas menengah di Indonesia sebanyak 10 juta jiwa dengan rata-rata penghasilan perbulan antara $\mathrm{Rp} 500.000,00$ (lima ratus ribu rupiah) - Rp 10.000.000,00 (sepuluh juta rupiah) maka dapat dibuat perhitungan sebagai berikut. ${ }^{41}$

Tabel Potensi Wakaf Uang di Indonesia

\begin{tabular}{|l|l|l|l|l|}
\hline $\begin{array}{l}\text { Tingkat Penghasilan } \\
\text { / bulan }\end{array}$ & $\begin{array}{l}\text { Jumlah } \\
\text { Muslim }\end{array}$ & $\begin{array}{l}\text { Tarif } \\
\text { Wakaf/bulan }\end{array}$ & $\begin{array}{l}\text { Potensi Wakaf } \\
\text { Tunai / bulan }\end{array}$ & $\begin{array}{l}\text { Potensi Wakaf } \\
\text { Tunai / tahun }\end{array}$ \\
\hline Rp 500.000 & 4 juta & Rp 5000,- & Rp 20 Milyar & Rp 240 Milyar \\
\hline $\begin{array}{l}\text { Rp 1 juta -Rp 2 } \\
\text { juta }\end{array}$ & 3 juta & Rp 10.000 & Rp 30 Milyar & Rp 360 Milyar \\
\hline $\begin{array}{l}\text { Rp 2 juta - Rp 5 } \\
\text { juta }\end{array}$ & 2 juta & Rp 50.000 & Rp 100 Milyar & Rp 1,2 Triliun \\
\hline $\begin{array}{l}\text { Rp 5 juta- Rp 10 } \\
\text { juta }\end{array}$ & 1 juta & Rp 100.000 & Rp 100 Milyar & Rp 1,2 Triliun \\
\hline \multicolumn{2}{|r|}{} \\
\hline
\end{tabular}

1. Apabila umat Islam yang berpenghasilan Rp500.000,00 sejumlah 4 juta orang dan setiap tahun masing-masing berwakaf sebanyak Rp60.000,00 maka setiap tahun terkumpul Rp240.000.000.000,00.

2. Apabila umat yang berpenghasilan Rp1.000.000,00 - Rp2.000.000,00 sejumlah 3 juta orang dan setiap tahun masing-masing berwakaf Rp120.000,00 maka setiap tahun terkumpul dana sebanyak Rp360.000.000.000,00.

3. Apabila umat yang berpenghasilan Rp2.000.000,00 - Rp5.000.000,00 sejumlah 2 juta orang dan setiap tahun masing-masing berwakaf

${ }^{41}$ Mustafa Edwin Nasution dan Uswatun Hasanah (Editor), Wakaf Tunai Inovasi Finansial Islam, Peluang dan Tantangan dalam Mewujudkan Kesejahteraan Umat (Jakarta: PKTTI-UI, 2005), hal. 43-44. 
Rp600.000,00 maka setiap tahun terkumpul dana sebanyak Rp1.200.000.000.000,00.

4. Apabila umaat yang berpenghasilan Rp5.000.000,00 - Rp10.000.000,00 sejumlah 1 juta orang dan setiap tahun masing-masing berwakaf Rp1.200.000,00 maka setiap tahun terkumpul dana sebanyak Rp1,200.000.000.000,00.

Dengan demikian wakaf yang terkumpul selama satu tahun sejumlah Rp3.000.000.000.000,00. Berdasarkan contoh perhitungan di atas maka terlihat bahwa keberhasilan lembaga untuk memobilisasi dana wakaf akan sangat menentukan manfaat keberadaan lembaga wakaf. Yang menjadi masalah, uang tersebut tidak dapat langsung diberikan kepada mauquf'alaih, tetapi nazhir harus mengelola dan mengembangkannya terlebih dahulu. Yang harus disampaikan kepada mauquf 'alaih adalah hasil investasi dana Rp.3 triliun tersebut, sedangkan uang wakafnya sendiri tidak boleh berkurang sedikit pun.

Dalam konteks pemanfaatan cash waqf untuk dunia pendidikan, ada tiga filosofi dasar yang perlu ditekankan yaitu:

1. Alokasi cash waqf harus dilihat dalam bingkai "proyek yang terintegrasi", bukan bagian-bagian dari biaya-biaya yang terpisah-pisah. Contoh adalah anggapan dana wakaf akan habis bila dipakai untuk membayar gaji guru atau upah bangunan, sementara wakaf harus abadi. Dengan bingkai proyek sesungguhnya dana wakaf akan dialokasikan untuk program-program pendidikan dengan segala macam biaya yang terangkum di dalamnya.

2. Asas kesejahteraan nadzir. Sudah terlalu lama, nadzir sering kali diposisikan kerja asal-asalan alias lillahi ta'ala (dalam pengertian sisa-sisa waktu dan bukan perhatian utama) dan wajib "berpuasa". Sebagai akibatnya seringkali kinerja nadzir asal-asalan juga. Sudah saatnya, menjadikan nazdir sebagai profesi yang memberikan harapan kepada lulusan terbaik umat dan profesi memberikan kesejahteraan bukan saja di akhirat tetapi juga di dunia. Di Turki, Badan pengelola wakaf mendapatkan alokasi $5 \%$ dari net income wakaf. Di Bangladesh, kantor administrasi wakaf juga $5 \%$. Sementara The central waqf Council India mendapatkan sekitar $6 \%$ dari net income pengelolaan dana wakaf. Di Indonesia, maksimal 10\%.

3. Asas transparansi dan accountability di amna badan wakaf dan lembaga yang dibantunya harus malaporkan setip tahun akan proses pengelolaan dana kepada umat Islam dalam audited financial report termasuk kewajaran daripos biayanya. ${ }^{42}$

Tentu saja cara-cara pengembangan secara produktif di atas mengandung risiko kerugian, bahkan kegagalan. Investasi dana wakaf di instrumen-instrumen investasi Islami seperti obligasi syariah ataupun pada saham-saham perusahaan Islami yang

${ }^{42}$ Muhammad Syafii Antoni, Kata pengantar Buku Kabisi, hal. xiv-xv 
tergabung dalam Jakarta Islamic Index, misalnya mengandung market risk, yakni turunnya market value dari investasi tersebut. Penanaman modal langsung di sektor produksi, seperti agribisnis, real estate, perindustrian, perdagangan dan pertambangan, masing-masing memiliki karakteristik risiko yang berbeda, baik dari segi risiko usahanya maupun risiko yang terkait dengan proses bisnis dan produksinya. Pertambangan, misalnya, termasuk sektor yang berisiko tinggi, memerlukan investasi yang besar, namun menjanjikan return yang seimbang dengan risikonya. Di sisi lain, real estate sangat terkait dengan keadaan ekonomi makro nasional dan daya beli masyarakat. Namun risiko bukan harus dihindari, justru harus dikelola agar potensi pengembangan dapat direalisasikan dengan memeperhitungkan dan mengendalikan risiko-risiko yang mungkin terjadi.

Dalam pasal 11, dinyatakan bahwa tugas nazhir juga mencakup pengawasan dan perlindungan terhadap harta benda wakaf. Pengawasan dan perlindungan terhadap harta benda wakaf dimaksudkan untuk menjaga berkurangnya nilai harta benda wakaf, baik karena peristiwa-peristiwa force majeur maupun karena kerugian/kegagalan investasi.

Oleh karena itu, nazhir selain memenuhi syarat-syarat yang disebutkan dalam Pasal 10 ayat (1) Undang-undang Tentang Wakaf, yaitu a. warga negara Indonesia; b. beragama Islam; c. dewasa; d. amanah; e. mampu secara jasmani dan rohani; dan $\mathrm{f}$. tidak terhalang melakukan perbuatan hukum. Akan tetapi dalam pelaksanaannya nanti, supaya nazhir dapat bekerja secara profesional dalam mengelola wakaf maka nazhir khususnya nazhir wakaf uang juga harus memiliki berbagai kemampuan yang yang menunjang tugasnya ${ }^{43}$ sebagai nazhir wakaf produktif, yakni:

1. memahami hukum wakaf dan peraturan perUndang-Undangan yang terkait dengan masalah perwakafan. Seorang nadzir sudah seharusnya memahami dengan baik hukum wakaf dan peraturan perUndang-Undangan yang terkait dengan masalah perwakafan. Tanpa memahami hal-hal tersebut, penulis yakin nazhir tersebut tidak akan mampu mengelola wakaf dengan baik dan benar;

2. memahami pengetahuan mengenai ekonomi syari'ah dan instrumen keuangan syariah. Wakaf adalah salah satu lembaga ekonomi Islam yang sangat potensial untuk dikembangkan. Oleh karena itu sudah selayaknya seorang nadzir khususnya nadzir wakaf uang dituntut memiliki dan memahami ekonomi syariah dan instrumen keuangan syariah;

3. memahami praktik perwakafan khususnya praktif wakaf uang di berbagai Negara. Dengan demikian yang bersangkutan mampu melakukan inovasi dalam mengembangkan wakaf uang, sebagai contoh misalnya praktik wakaf uang yang dilakukan di Bangladesh, Turki, dan lain-lain;

${ }^{43} \mathrm{Hal}$-hal lebih detil tentang nazhir, termasuk mekanisme pemberhentiannya bisa dibaca lebih jelas di PP Nomor 42 Tahun 2006 Tentang Pelaksanaan UU No. 41 Tahun 2004 tentang wakaf bab II, pasal 2-14. 
4. mengelola keuangan secara professional dan sesuai dengan prinsip-prinsip syari'ah, seperti melakukan investasi dana wakaf. Investasi ini dapat dapat berupa investasi jangka pendek, menengah maupun jangka panjang;

5. melakukan administrasi rekening beneficiary. Persyaratan ini memerlukan teknologi tinggi dan sumber daya manusia yang andal; ${ }^{44}$

6. mengakses ke calon wakif. Idealnya pengelola wakaf uang adalah lembaga yang ada kemampuan melakukan akses terhadap calon wakif, sehingga nadzir mampu mengumpulkan dana wakaf cukup banyak. Kondisi demikian jelas akan sangat membantu terkumpulnya dana wakaf yang cukup besar sehingga diharapkan dapat meningkatkan kesejahteraan umat;

7. melakukan distribusi hasil investasi dana wakaf. Disamping mampu melakukan investasi, diharapkan nazhir juga mampu mendistribusikan hasil investasi dana wakaf kepada mauquf 'alaih. Diharapkan pendistribusiannya tidak hanya bersifat konsumtif, tetapi dapat memberdayakan mauquf'alaih;

8. mengelola dana wakaf secara transparan dan akuntabel. ${ }^{45}$

Untuk meningkatkan kualitas nazhir tersebut, maka pembinaan terhadap mereka perlu segera dilakukan. Untuk di dalam Undang-Undang 41 Tahun 2004 tentang Wakaf diamanatkan perlunya dibentuk Badan Wakaf Indonesia. Dalam Pasal 47 ayat (1) Undang-Undang Tentang Wakaf disebutkan bahwa dalam rangka memajukan dan mengembangkan perwakafan nasional, dibentuk Badan Wakaf Indonesia. Badan Wakaf Indonesia tersebut berkedudukan di ibukota Negara Kesatuan Republik Indonesia dan dapat membentuk perwakilan di provinsi dan/atau kabupaten/kota sesuai dengan kebutuhan (Pasal 48). Dalam Pasal 51 ayat (1) disebutkan bahwa Badan Wakaf Indonesia terdiri atas Badan Pelaksana dan Dewan Pertimbangan. Keanggotaan Badan Wakaf Indonesia diangkat untuk masa jabatan selama 3 (tiga) tahun dan dapat diangkat kembali untuk 1 (satu) kali masa jabatan.

Dalam Pasal 57 ayat (1) disebutkan bahwa untuk pertama kali pengangkatan keanggotaan Badan Wakaf Indonesia diusulkan kepada Presiden oleh Menteri (Menteri Agama). Alhamdulillah, setelah melalui proses yang cukup panjang, pada akhirnya Menteri Agama Republik Indonesia telah berhasil memilih calon anggota Badan Wakaf Indonesia untuk diusulkan kepada Presiden. Pada tanggal 13 Juli 2007, Keputusan Presiden Republik Indonesia tentang pengangkatan anggota Badan Wakaf Indonesia tersebut ditandatangani Presiden Susilo Bambang Yudoyono.

Dengan demikian, pengelolaan risiko pengelolaan dan pengembangan dana wakaf harus melibatkan proses manajemen risiko yang ketat dan profesional di dalam tubuh BWI sendiri, sebelum mendisimenasikan risk awareness dan risk conciousness

\footnotetext{
${ }^{44}$ Lihat juga: Muhammad Syafi'I Antonio "Bank Syariah Sebagai Pengelola Dana Waqaf", disampaikan pada Workshop Internasional Pemberdayaan Ekonomi Umat Melalui Pengelolaan Wakaf Produktif, diselenggarakan oleh DEPAG-IIIT, 7-8 Januari 2002.

${ }^{45}$ Uswatun, op.cit., hal. 28-29
} 
serta mengaplikasikan teknik manajemen risiko kepada perwakilan BWI di daerah maupun nazhir-nazhir di seluruh Indonesia. Menjadi kewajiban BWI untuk memastikan bahwa pengelolaan dan pengembangan dana wakaf telah melalui proses manajemen risiko yang baik.

Karena itu, yang perlu menjadi perhatian utama bagi anggota BWI adalah merintis kerjasama dengan berbagai instansi, baik pemerintah maupun swasta, organisasi masyarakat, para ahli, perguruan tinggi, badan internasional dan lain-lain.

Nah, dalam konteks Indonesia, Lembaga Keuangan Syariah idealnya harus mampu bermitra dengan para nazhir untuk mengembangkan wakaf uang di Indonesia ke arah yang lebih produktif. Pada 9 September, Menag Maftuh Basyuni memutuskan lima nama LKS Penerima Wakaf Uang (PWU), yaitu Bank Muamalat Indonesia, Bank Syariah Mandiri, BNI Syariah, Bank DKI Syariah, dan Bank Mega Syariah. Ini momentum pengembangan wakaf produktif melalui instrumen wakaf uang. Potensi wakaf uang terbilang besar.

Untuk mengoptimalkan potensi besar itu, LKS berperan sebagai mitra kerja BWI dan para nazhir. ${ }^{46}$ Dalam menggalang wakaf uang, LKS dipilih sebagai mitra karena punya beberapa kelebihan. Pertama, jaringan kantor yang membantu nazhir menghimpun wakaf uang. Luas jaringan ini mampu menjangkau hampir seluruh wilayah Indonesia. Tingkat pertumbuhan jumlah kantor LKS 2,1 persen per bulan. Ini faktor penting dalam memaksimalkan sosialisasi dan penggalangan wakaf uang.

Kedua, jaringan delivery channel. Jaringan ini meliputi ATM, EDC, phone banking, mobile banking, dan internet banking. Efektivitas dan efisiensi jaringan ini patut dibanggakan. Banyak orang berbondong-bondong mengunduh manfaat dan kemudahan dari kemajuan teknologi. Ini pun ceruk strategis yang mesti dimanfaatkan untuk menjaring wakaf uang.

Ketiga, jaringan mitra atau aliansi. LKS telah berjejaring dengan berbagai mitra terkait. Melalui jaringan itu, LKS bisa memasuki kawasan Nusantara. Pengalaman LKS dalam bermitra menjadi faktor yang akan selalu dipertimbangkan dalam mengoptimalkan penghimpunan wakaf uang. Faktor itu juga memungkinkan membentuk database informasi mengenai sektor usaha ataupun debitur yang akan dikembangkan. ${ }^{47}$

${ }^{46}$ Alternatif peran perbankan syariah dalam pengelolaan wakaf tunai adalah sebagai (1). Bank Syariah sebagai Nadzir Penerima, Penyalur dan Pengelola Dana Dana Wakaf, (2). Bank Syariah sebagai Nadzir Penerima dan Penyalur Dana Wakaf, (3).Bank Syariah sebagai Pengelola (Fund Manager) Dana Wakaf, dan (4).Bank Syariah sebagai Kustodi. Lihat Mustofa Edwin Nasution, op.cit., hal. 108-117.

${ }^{47}$ Thalhah Hasan (Ketua Badan Pelaksana Badan Wakaf Indonesia (BWI)) (2009), Peran LKS di Era Wakaf Produktif, http://bw-indonesia.net/, Senin, 09 Maret 2009, accessed 10 Agustus 2009. Lihat Pedoman pengelolaan wakaf produktif dalam DEPAG RI, Pedoman Pengelolaan dan Pengembangan Wakaf. (Jakarta: Direktorat Pemberdayaan Wakaf, 2006), hal. 105-126. Lihat juga Farid Wadjdy dan Mursyid, Wakaf dan Kesejahteraan Umat (Filantropi Islam yang Hampir Terlupakan. (Yogyakarta: Pustaka Pelajar, 2007), hal. 108-122. 
Selain menjaring wakaf uang, LKS juga dapat berperan sebagai mitra dalam pengembangan aset wakaf ke arah yang lebih produktif. Ada beberapa alternatif model kerja sama. Pertama, hukr atau sewa berjangka panjang. Model ini memosisikan LKS sebagai pengendali atau manajer yang menyewa tanah wakaf untuk periode jangka panjang. LKS mengambil tanggung jawab konstruksi dan manajemen serta membayar ongkos sewa secara periodik kepada nazhir.

Kedua, murabahah. Nazhir memosisikan dirinya sebagai pengusaha pengendali proses investasi yang membeli berbagai keperluan proyek wakaf, seperti material dan peralatan kepada LKS. Pembayarannya dibayar kemudian, diambilkan dari pendapatan hasil pengembangan wakaf.

Ketiga, mudharabah. Model ini dapat digunakan nazhir sebagai mudharib dan menerima dana likuid dari LKS untuk mendirikan bangunan di atas tanah wakaf. Manajemen akan tetap berada di tangan nazhir dan tingkat bagi hasil diterapkan untuk menutup biaya usaha dalam manajemen sebagaimana juga penggunaan tanahnya.

Tiga model di atas sebatas contoh yang dapat dikembangkan lebih jauh. Pada intinya, nazhir mempunyai kapabilitas dan jaringan yang luas untuk mengembangkan aset wakaf. Pengembangan aset atau investasi ini untuk mengoptimalkan fungsi harta wakaf sebagai prasarana menciptakan kesejahteraan sosial dan membangun peradaban umat, seperti memajukan pendidikan, pengembangan rumah sakit, pemberdayaan ekonomi masyarakat, dan penciptaan lapangan pekerjaan.

Fungsi ini diakui kurang maksimal sebab pemanfaatan aset wakaf kebanyakan masih dikelola secara tidak profesional atau konsumtif. Dengan terbitnya Keputusan Menteri Agama tentang nama-nama LKS PWU, akan menggairahkan semangat nazhir mengembangkan harta wakaf ke arah yang lebih produktif melalui wakaf uang yang bekerja sama dengan LKS.

Sudah saatnya nazhir mengubah paradigma dalam pengelolaan aset wakaf dari menunggu bola menjadi menjemput bola, dari meminta-minta menjadi menjalin mitra. Itulah yang disebut sebagai financial engineering dalam makna pengembangan aset wakaf. Dengan begitu, diharapkan tak ada lagi aset wakaf yang tidak produktif, apalagi telantar dan tak jelas statusnya. ${ }^{48}$

Apalagi, pada 2008 lalu DPR telah mensahkan RUU Surat Berharga Syariah Negara (SBSN) dan perbankan Syariah. Artinya, instrument untuk mengembangkan produktifitas perwakafan di Indonesia kian terbuka lebar. Tinggal kita selaku umat Islam di Indonesia, bisa memanfaatkan peluang atau tidak. ${ }^{49}$

Di samping itu semua, wakaf juga harus dipromosikan dan service-nya ditingkatkan. Tujuan dari Promosi ini adalah memberitahukan, menyadarkan, mengingatkan, mendorong dan memotivasi, menanamkan citra yang kuat dalam benak, dan memudahkan dan malayani.

${ }^{48}$ Ibid. Republika, 31 Oktober 2008 accessed 3 Juli 2009

${ }^{49}$ Padang Ekspres, Rabu, 28 Mei 2008 accessed 3 Juli 2009 
Adapun bentuk atau cara promosi yang dapat dilakukan meliputi beberapa hal, seperti sebagai berikut:

1. Surat, contohnya surat penawaran atau ajakan/dakwah untuk berwakaf.

2. Presentasi, baik pesentasi perorangan atau kelompok/ lembaga.

3. Barang cetakan, seperti: brosur, leaflet, poster dan flier.

4. Perhatian, contohnya adalah: tampilan dan informasi.

5. Branding informasi ke masyarakat dengan mengintegrasikan berbagai potensi media pada waktu bersamaan.

6. Penerbitan, seperti jenis media, sasaran konsumen, pesan, buku, buletin, majalah, Koran, dll.

7. Perhatian penulisan, seperti: informasi, bentuk, lokasi, waktu dan gaya, mandiri dan kerja sama.

8. Iklan, contohnya seperti: iklan dimedia cetak, televisi, radio, internet, media pertemanan (facebook, twiter dan lain-lain), dan media luar ruangan.

9. Asesoris dan gift, seperti: Boolpoint, sticker, gantungan kunci, pembatas buku, kaos, topi, kalender, buku agenda dan lain-lain.

10. Event, contohnya adalah seperti seminar, pelatihan, lomba, festival, malam amal atau kegiatan sosial lainnya.

11. Pengabdian kepada masyarakat, dan lain-lain.

Beberapa faktor yang harus diperhatikan dalam promosi antara lain: sasaran komunitas donatur yang dituju; daya jangkau alat promosi (coverage area); ketepatan waktu penggunaan; kata-kata, gaya bahasa dan gambar yang digunakan; biaya yang harus digunakan; dan daya pengaruh atau bentuk respon yang diharapkan.

Sedangkan peningkatan pelayanan transaksi wakaf baik benda tidak bergerak maupun benda bergerak termasuk wakaf uang dapat dicatat yang kemudian dibimbing prosesinya melalui saluran yang ada (PPAIW/ Kantor KUA, Notaris, dan LKS-PWU untuk wakaf uang). Pelayanan transaksi untuk sumbangan operasional pengelolaan wakaf dapat dilakukan dengan berbagai pilihan yang cocok secara parsial atau kombinasi dari daftar di bawah ini:

1. Bayar langsung

2. Transfer via rekening bank

3. Debet langsung setiap bulan dari rekening donatur

4. Pembayaran via phone banking

5. Pembayaran via ATM

6. Pembayaran via kartu debet

7. Pembayaran via SMS

8. Pembayaran via internet

9. Pemotongan laba perusahaan

10. Pemotongan gaji pegawai 
Syafrudin Arif: Wakaf Tunai...

\section{Penjualan merchandise}

12. Sponsorship, dan lain-lain. ${ }^{50}$

\section{Teori Redistribusi Ekonomi dan Wakaf Tunai}

Dalam ekonomi konvensional, telah berkembang mengenai perlunya redistribusi ekonomi dalam masyarakat. Ada dua teori besar dalam hal itu. Namun sebelumnya, di sini perlu dijelaskan bahwa arti "redistribusi ekonomi" adalah penyebaran kekayaan dari suatu masyarakat kepada masyarakat tertentu secara tunai atau dengan cara lain. Hal itu juga mencakup pembiayaan layanan publik seperti kesehatan dan pendidikan yang dilakukan oleh sekelompok orang kepada yang lainnya. Satu pihak menerima manfaat dan pihak lainnya memberikan manfaat. Agen (pelaku) redistributif berfungsi sebagai perantara (intermediari) antara kedua pihak tersebut.

Ada 3 macam pelaku redistribusi: pemerintah, perorangan, dan lembaga swasta sebagai wadah yang mewakili himpunan perorangan. Program yang dilakukan tiga agen tersebut seperti pajak, infaq (derma), beasiswa, termasuk wakaf dan semua itu disebut mekanisme redistributif.

Dalam literatur ekonomi, ada dua bentuk pembahasan mengenai redistribusi. $^{51}$ Bentuk pertama adalah bentuk diskusi yang mempertanyakan aspek normatif. Dalam hal ini, mereka membahas tentang: apakah redistribusi perlu? Siapakah yang melakukannya redistribusi? Apakah efisiensi ekonomis (economic efficiency) itu lebih utama ketimbang persamaan ekonomi (economic equality)? Ada dua kelompok yang berseberangan pandangan sehubungan dengan diskusi masalah normatif ini, yaitu Pareto Criterion dan Liberalisme. Bentuk kedua adalah diskusi yang membahas tentang: mengapa kita mesti memperhatikan redistribusi ekonomi dalam masyarakat? Terkait dengan dua diskusi itu, tulisan ini mengambil posisi pada diskusi kedua. Sehingga tidak perlu dipersoalkan lagi mengenai arti pentingnya redistribusi.

Tujuan teori redistribusi adalah menjelaskan keberadaan redistribusi dalam masyarakat. Sedangkan dari sudut pandang pelaku/penggerak redistribusi (redistributive agent), maka redistribusi dibagi menjadi dua kelompok. Kelompok pertama mengambil peran perorangan yang menjelaskan mengapa seseorang menyebarkan pendapatannya kepada orang lain. Kelompok kedua, kebalikannya, menjadikan pemerintah sebagai penggerak redistribusi (the redistributive agent), yang menjelaskan mengapa pemerintah berperanserta dalam tindakan redistribusi (redistributive actionsi). Mayoritas teori ekonomi termasuk dalam kelompok kedua. Sementara itu, teori yang menegaskan bahwa lembaga swasta dapat berfungsi sebagai penggerak redistribusi (redistributive agent) hampir tidak ada. ${ }^{52}$

50 Suparman IA, "Manajemen Fundraising dalam Penghimpunan Harta Wakaf", (dengan beberapa modifikasi oleh penulis) dalam www.bw-indonesia.net/ diakses 3 Juli 2009.

${ }^{51}$ Birol Baskan, Waqf... Ibid., hal. 3.

${ }^{52}$ Ibid., hal. 4. 
Kelompok pertama diwakili oleh Becker (1974). ${ }^{53}$ Teori Becker bertitik tolak dari fungsi utilitas rumah tangga. Fungsi utilitas tumah tangga bergantung pada komoditas (barang dagangan) dan kebutuhan-kebutuhan keluarga. Rumusnya adalah sebagai berikut:

(1) $\mathrm{U}_{\mathrm{i}}=\mathrm{U}_{\mathrm{i}}(\mathrm{X}, \mathrm{R})$

$\mathrm{X}$ menunjukkan komoditas yang tersedia untuk kebutuhan konsumsinya; $\mathrm{R}$ menunjukkan kebutuhan-kebutuhan bersamanya. Dalam teori klasik tentang perilaku rumah tangga, ahli ekonomi mengganggap $\mathrm{R}$ sebagai baku (pasti), sehingga mengeluarkan fungsi utilitasnya karena hal itu bukan merupakan persoalan pilihan. Kemudian Becker membedakan fungsi utilitasnya dari teori klasik. Bedanya Teori Becker memasukkan kebutuhan-kebutuhan bersama, sementara utilitas menurut teori klasik terkait dengan barang-barang umumnya dan layanan-layanan. Tidak seperti teori klasik, Becker berpandangan bahwa rumah tangga dapat mengubah Rji dengan usahanya sendiri. Selain daripada itu, Becker tidak sependapat dengan pengertian konvensional tentang pendapatan (income). Sehingga dia memperkenalkan istilah "pendapatan bersama (Social Income)." pendapatan bersama (Social Income) adalah sejumlah pendapatan rumah tangga dan nilai keuangan, menurutnya, terkait dengan karakteristik dari sesuatu selainnya atau dari lingkungan sosialnya. Dalam pengertian matrik, dia menulis pendapatan bersama dari persorangan sebagai i pada rumus berikut:

(2) $I_{i}=p_{x} x+p_{h} R$

$\mathrm{p}_{\mathrm{x}}$ adalah harga pada barang konsumsi $\mathrm{x}$ dan $\mathrm{p}_{\mathrm{h}} \mathrm{h}$ adalah besaran keuangan rumah tangga yang telah habiskan untuk mengubah $R$. yang menghasilkan sejumlah (a) hambatan (b) menciptakan keadaan optimal yang diperlukan: rumus pengeluaran yang optimal (optimal expenditure pattern) adalah pada pengertian di mana rasio utilkitas marginal dari konsumsi dan lingkungan sosial adalah sama dengan rasio harga. Jadi rumah tangga i menghabiskan pendapatannya I untuk komsumsi terhadap barang dagangan $\mathrm{X}$ dan untuk upaya-upaya mengubah lingkungan sosialnya. Pemberian derma (infaq) hanya merupakan tindakan khusus dalam kerangka umum pemikiran ini.

Dengan demikian, rumah tangga i memperhatikan konsumsi rumah tangga $\mathrm{j}$ berupa barang dagangan (komoditas) $\mathrm{X}$. Oleh karena itu, Becker menulis fungsi utilitasnya sebagai berikut:

${ }^{53}$ Gary S. Becker menerima Nobel Prize atas upayanya menjelaskan analisa microeconomic pada perilaku dan interaksi manusia, yang mencakup perilaku non-pasar (non-market behavior) pada 1992. Tulisannya berjudul "A Theory of Social Interactions." Journal of Political Economy 82, no:6 (1974) 1063-1091. 
(3) $\mathrm{U}_{\mathrm{i}}=\mathrm{U}_{\mathrm{i}}\left(\mathrm{x}_{\mathrm{i}}, \mathrm{x}_{\mathrm{j}}\right)$

$x_{j}$ adalah konsumsi rumah tangga $j$ yang sama dengan $\left(I_{j}+h\right) / p_{j}$. yang menghasilkan (c) persoalan anggaran (budget), sehingga hasilnya adalah $\mathrm{I}_{\mathrm{i}}=\mathrm{p}_{\mathrm{i}} \mathrm{x}_{\mathrm{i}}+\mathrm{p}_{\mathrm{j}} \mathrm{x}_{\mathrm{j}}$. Jadi rumah tangga $\mathrm{i}$ menghabiskan pendapatannya untuk konsumsi barang dagangan (komoditas) X untuk dirinya sendiri dan untuk rumah tangga $j$. Becker berpandangan lebih jauh bahwa rumah tangga i dan penerima infaqnya menghasilkan keluarga sintetik (a synthetic family). Dampak dari pandangan inilah yang menarik, yaitu bahwa infaq/derma adalah suatu "bentuk asuransi/perlindungan diri sendiri yang merupakan pengganti asuransi pasar dan pelimpahan pemerintah (Charity is a form of self-insurance that is a substitute for market insurance and government transfers)." 54

Dengan demikian, dalam menjalankan peranan wakaf tunai sebagai alternatif mekanisme redistribusi ekonomi, setidaknya ada dua peranan yang menentukan dalam reaslisasinya. Peranan pertama, negara mempunyai peranan yang krusial. Negara dapat menyerahkan "lahan nganggur" secara terang-terangan dan legal sebagai "wakaf" ataupun menyerahkan sejumlah uang sebagai "wakaf tunai" kepada pihak-pihak yang lemah secara ekonomi atau pihak yang kuat secara ekonomi yang berpotensi menjalankan usaha yang menguntungkan sehingga dapat menyerap tanaga kerja. Peranan kedua, negara/pemerintah menciptakan ataupun menguatkan sistem wakaf dengan cara membina, mengawasi, dan mencatat pemasukan dan pengeluaran dari sistem wakaf tersebut.

\section{Penutup}

Kemiskinan dan ketimpangan pendapatan merupakan persoalan rumit yang dihadapi oleh negara. Sifatnya massif dan struktural serta meluas yang terjadi pada setiap lapisan masyarakat. Oleh karena itu, karena negara mempunyai dan memegang kekuasaan sekaligus kekuatan ekonomi paling besar. Sehingga negaralah yang sewajarnya mengemban tugas mulia untuk mengentaskan kemiskinan. Sekalipun begitu, tidak menutup kemungkinan setiap lapisan masyarakat mempunyai peranan yang signifikan dalam mengentaskan kemiskinan. Bahkan peran agama juga sangat dimungkinkan dalam hal ini. Sebagaimana ditunjukkan dalam ajaran Islam tentang zakat dan juga wakaf, penerapan keduanya berpotensi besar mengurangi secara signifikan angka kemiskinan yang bersifat "struktural" tersebut. ${ }^{55}$.

\footnotetext{
${ }^{54}$ Dia menjelaskan lagi bahwa "pertumbuhan cepat asuransi swasta dan pelimpahan pemerintah selama 100 tahun ini digairahkan oleh pertumbuhan infaq/derma (presumably the rapid growth of these latter (private insurance and government transfers) during the last 100 years discouraged the growth of charity)." Ibid. hal.1084.

${ }^{55}$ Riza Prima Henda, dkk. (2003). Kemiskinan dan Kemandirian: Catatan Perjalanan dan Refleksi Bina Swadaya. Jakarta: Yayasan Bina Swadaya, hal. 37. Kemiskinan struktural adalah keadaan serba
} 
Bersama ajaran-ajaran Islam lainnya terkait dengan ekonomi, ajaran wakaf juga sangat berpotensi mengurangi kemiskinan dan kehidupan ekonomi yang serba kekurangan pada masyarakat. Tentu saja, di Indonesia bahkan di dunia, program pengentasan kemiskinan tidak lagi menjadi tugas negara. Sekalipun begitu, negara memang memegang perang paling besar. Karena dengan kapasitas dan kualitas negara, maka negara-lah pengemban amanah dari setiap warga negaranya. Peran penting negara tampak sangat vital apalagi sehubungan dengan kemiskinan "struktural" yang ditimbulkan akibat ketimpangan dari aplikasi kebijakan negara. Dengan demikian, potensi wakaf dalam mengurangi kemiskinan tidak dapat dilihat dari persoalan mikro ekonomi Islam saja.

Oleh karena itu, potensi wakaf tunai khususnya di Indonesia yang luar biasa sebagaimana dijelaskan di atas harus mendapatkan penanganan manajemen yang profesional. Hal itu dapat terwujud, jika masyarakat telah memahami dasar hukum dan potensi wakaf tunai. Akhirnya, perubahan paradigma perwakafan tradisional menjadi wakaf produktif dalam bentuk wakaf tunai merupakan kesadaran yang semestinya diingatkan demi terjadinya peningkatan kualitas hidup dan kebagiaan umat Islam dunia-akhirat. Upaya penyadaran perlu dilakukan terus-menerus.

\section{DAFTAR PUSTAKA}

Abdullah Ubaid Matraji (Staf Divisi Humas Badan Wakaf Indonesia), Republika Newsroom, Kamis, 05 Februari 2009, accessed 3 Juli 2009.

Abu Su'ud Muhammad, Risalah fi Jawazi Waqf al-Nuqud, (Beirut: Dar Ibn Hazm, 1997).

Al-Imam Kamal al-Din Ibn 'Abd al-Rahid al-Sirasi Ibn al-Humam, Sharh Fath alQadir, jilid 6. (Beirut: Dar al- Kutub al-'Ilmiyyah, 1970)

Al-Mawardi, al-Hawi al-Kabir, juz IX, tahqiq Mahmud Mathraji, (Beirut: Dar alFikr, 1994)

Birol Baskan, Waqf System As A Redistribution Mechanism In Ottoman Empire, Chicago: Northwestern University Department of Political Science, 2002, April.

Crecelius, Daniel, "Introduction," Journal of the Economic and Social History of the Orient, Leiden: E.J.Brill, v.38, part 3 (august), 1995.

DEPAG RI, Pedoman Pengelolaan dan Pengembangan Wakaf. (Jakarta: Direktorat Pemberdayaan Wakaf, 2006)

DEPAG RI, Peraturan Perundangan Perwakafan. (Jakarta: DEPAG RI, 2006)

kekurangan yang diikuti oleh berbagai keadaan yang menekan kehidupan yang saling mempengaruhi dan menyejarah. Keadaan tersebut bukanlah keadaan yang dikehendaki oleh si miskin, melainkan sesuatu yang tidak bisa dihindari dengan kekuatan yang ada pada dirinya. Tidak terpenuhinya berbagai kebutuhan dan pelayanan dasar yang diperlukan oleh seseorang untuk hidup dan berkembang secara layak. 
Syafrudin Arif: Wakaf Tunai...

Dian Masyita, Muhammad Tasrif, dan Abdi Suryadinata Telaga, "A Dynamic Model for Cash Waqf Management as One of The Alternative Instruments for the Poverty Alleviation in Indonesia," hal. 1 diakses dari http://www.islamicworld.net.

Direktorat Pemberdayaan Wakaf, "Data Luas dan Lokasi Tanah Wakaf Nasional Sampai Dengan Tahun 2008”, Jakarta, 22 April 2008.

Elsi Kartika Sari, Pengantar Hukum Zakat dan Wakaf. (Jakarta: Grasindo, 2006)

Farid Wadjdy dan Mursyid, Wakaf dan Kesejahteraan Umat (Filantropi Islam yang Hampir Terlupakan. (Yogyakarta: Pustaka Pelajar, 2007)

Habib Ahmed, Role of Zakah and Awqaf in Poverty Alleviation. (Jeddah: IRTI, 2004)

Ibn Manzur, Lisan al-Arab, jil. 11. (Kairo: al-Dar al-Misriyyah li al-Ta'lif wa alTarjamah, 1954)

Ibn Qudamah, Al-Mughni Wa al-Syarh al-Kabir, jil. 6. (Beirut: Dar al-Kutub al-'Arabi, 1972)

Imam Muhammad bin Ismail al-Kahlani, Subul al-Salam. (Bandung: Maktabah Dahlan, tt.)

Ismail bin Umar bin Kasir, Tafsir Ibnu Katsir, (Riyad: Dar al-Salam, 2001)

Muhammad Abid Abdullah al-Kabisi, Ahkam al-Waqf fi al-Syariah al-Islamiyah. (Baghdad: Mathba'ah al-Irsyad, 1977). Alih bahasa Ahrul Sani Faturrahman dkk, judul Indonesia: Hukum Wakaf, (Jakarta: DD Republika dan IIMan, 2004)

Muhammad Ahmad Alisy, Syarh Minah al-Jalil ala Mukhtashar Khalil, (Mesir: Penerbit al-Kubra, $1294 \mathrm{H}$ )

Muhammad al-Khatib al-Syarbini, Mughni al-Muhtaj, juz 2. (Kairo: Syarikah Maktabah wa Matba'ah Mustafa al-Babi al-Halabi wa Awladih, 1958)

Muhammad Syafii Antonio, "Cash Waqf dan Anggaran Pendidikan”, dalam Kumpulan Hasil Seminar Perwakafan. (Jakarta: Depag RI, 2004) , Kata pengantar Buku Kabisi, hal. xiv-xv

Munzir Kahaf, Manajemen Wakaf Wakaf Produktif, diterjemahkan oleh Muhyiddin Mas Rida, (Jakarta: Khlmifa, 2005)

Murat Cizakca, Ottoman Cash Waqfs Revisited: The Case of Bursa 1555-1823, UK: FSTC, 2004.

Mustafa Edwin Nasution dan Uswatun Hasanah (Editor), Wakaf Tunai Inovasi Finansial Islam, Peluang dan Tantangan dalam Mewujudkan Kesejahteraan Umat (Jakarta: PKTTI-UI, 2005)

Padang Ekspres, Rabu, 28 Mei 2008 accessed 3 Juli 2009

PP Nomor 42 Tahun 2006 Tentang Pelaksanaan UU No. 41 Tahun 2004 tentang wakaf 
Republika, 31 Oktober 2008 accessed 3 Juli 2009

Riza Prima Henda, dkk. Kemiskinan dan Kemandirian: Catatan Perjalanan dan Refleksi Bina Swadaya. Jakarta: Yayasan Bina Swadaya, 2003.

Sayyid Sabiq, Figh al-Sunnah, Beirut: Dar al-Fikr, 1983)

Suparman IA, "Manajemen Fundraising dalam Penghimpunan Harta Wakaf”, (dengan beberapa modifikasi oleh penulis) dalam www.bw-indonesia.net/ diakses 3 Juli 2009.

Syafi'i Antonio “Bank Syariah Sebagai Pengelola Dana Waqaf”, disampaikan pada Workshop Internasional Pemberdayaan Ekonomi Umat Melalui Pengelolaan Wakaf Produktif, diselenggarakan oleh DEPAG-IIIT, 7-8 Januari 2002.

Syams al-Din al-Syaikh Muhammad al-Dasuqi, Hasyiyah al-Dasuqi 'ala al-Syarh alKabir, juz 2. (Beirut: Dar al-Fikr, tt.)

Thalhah Hasan (Ketua Badan Pelaksana Badan Wakaf Indonesia (BWI)) (2009), Peran LKS di Era Wakaf Produktif, http://bw-indonesia.net/, Senin, 09 Maret 2009, accessed 10 Agustus 2009.

Tholhah Hasan (2009), "Perkembangan Kebijakan Wakaf di Indonesia", dalam Republika, Rabu, 22 April 2009, accessed 3 Juli 2009.

Undang-undang Nomor 41 Tahun 2004 tentang wakaf

Uswatun Hasanah, Wakaf Produktif Untuk Kesejahteraan dalam Perspektif Hukum Islam di Indonesia. (Jakarta: Naskah Pidato Pengukuhan Guru Besar di Universitas Indonesia, 6 April 2009)

Wahbah al-Zuhaili, al-Figh al-Islam wa Adillatuhu, juz VIII (Damaskus: Dar al-Fikr, 1985) 